University of California, Hastings College of the Law UC Hastings Scholarship Repository

Faculty Scholarship

1995

\title{
Courting Justice? Legitimation in Lawyering Under Israeli Occupation
}

George Bisharat

UC Hastings College of the Law, bisharat@uchastings.edu

Follow this and additional works at: http://repository.uchastings.edu/faculty_scholarship

Part of the International Law Commons

\section{Recommended Citation}

George Bisharat, Courting Justice? Legitimation in Lawyering Under Israeli Occupation, 20 Law \& Soc. Inquiry 349 (1995). Available at: http://repository.uchastings.edu/faculty_scholarship/37

This Article is brought to you for free and open access by UC Hastings Scholarship Repository. It has been accepted for inclusion in Faculty Scholarship by an authorized administrator of UC Hastings Scholarship Repository. For more information, please contact marcusc@uchastings.edu. 


\section{Courting Justice? Legitimation in Lawyering under Israeli Occupation}

George E. Bisharat

Israel has since 1967 administered the West Bank and Gaza Strip through highly legalistic and strongly repressive military governments. Has advocacy in Israeli courts on behalf of Palestinian residents of the West Bank and Gaza Strip has legitimated, and thus helped to perpetuate, ongoing Israeli military occupation of those regions? By examining legitimation in lawyering under Israeli occupation, insight can be gained into the factors and their relative weights that lawyers facing harsh or repressive regimes must consider in balancing the costs and benefits of litigation to serve a social or political opposition movement. The author concludes that the benefits outweigh the legitimating effects of lawyers' work and that, on balance, Palestinians' election to seek representation in Israeli courts, and lawyers' choice to assist them, has been justified.

Since 1967, Israel has administered the West Bank and Gaza Strip through military governments at once highly legalistic and strongly repressive, and lawyers committed to defending the interests of Palestinian residents of those regions have faced a dilemma: Should they accept invitation into the courts of the occupying power, to defend clients and press their claims? Or would they, in doing so, validate Israelis' assertions that theirs was a "benign occupation" and so sap urgency from calls to end the occupation?

George E. Bisharat is an associate professor of law, Hastings College of the Law, University of California. The author has benefited from the able assistance of student researchers Farzad Tabatabai, Khaldoun Baghdadi, and Nagy Morcos. The comments of six anonymous readers of an earlier draft were extremely helpful, as were those of Lisa Hajjar, Neil Hicks, Jane Winn, Linda Bevis, Jonathan Kuttab, and James Ron. He is especially indebted to Stephen Ellmann, who first invited him to address the topic on a panel at the Law and Society Association annual meeting in Philadelphia, May 1992, and has further shepherded the works of the panelists to publication.

(c) 1995 American Bar Foundation.

0897-6546/95/2002-0349\$01.00 
I review here the possibility that advocacy in Israeli courts on behalf of Palestinian residents of the West Bank and Gaza Strip has legitimated, and thus helped to perpetuate, ongoing Israeli military occupation of those regions. ${ }^{1}$ Further, I attempt to measure the benefits Palestinians have gained by this advocacy and to weigh them against any identifiable legitimation costs $^{2}$ incurred in the process. These issues were implicit in my 1989 book on the West Bank legal profession, Palestinian Lawyers and Israeli Rule: Law and Disorder in the West Bank, ${ }^{3}$ but were tangential to its central theme and therefore were never squarely addressed there.

These questions were not rendered moot by the signing of the September 1993 peace agreement between Israel and the PLO. ${ }^{4}$ Even had they been, I believe that by examining legitimation in lawyering under Israeli occupation, we can gain significant insight into the particular matrix of factors that lawyers facing harsh or repressive regimes must consider in balancing the costs and benefits of litigation in the service of a social or political opposition movement.

I argue that while lawyers' efforts to constrain the policies and actions of the Israeli occupation administration have had some legitimation costs, at least in some quarters, these costs have been relatively minimal. While the tangible benefits achieved by lawyers seeking to vindicate Palestinian

1. "Legitimation" involves "the attempt by those engaged in some realm of social activity to offer a normative justification for their actions." Abel, "Why Does the ABA Promulgate Ethical Rules?" 59 Tex. L. Rev. 639, 686 (1981). Legitimation does not come about merely from an attempt to provide normative justification for some actions, of course, but only from some relevant audience's acceptance of that justification. While the identity of such audiences varies with circumstances, I have argued that, as a general matter, law in its legitimating function may be effective primarily among those near the centers of social and political power and that law's legitimating power diminishes steadily within increasingly marginal groups or classes in society. See George E. Bisharat, "Land, Law, and Legitimacy in Israel and the Occupied Territories," 43 Am. U.L. Rev. 467 (1994), where I posited that the legal regime implemented to acquire Palestinian land in Istael and the Occupied Territories finessed the contradiction between the Zionist movement's foundational need to gain land for Jewish settlement and Israel's democratic ideology. The current article is, in a sense, a sequel to the first, inasmuch as it explores the manner in which Israel, by use of laws and legal institutions, rationalized and legitimated its suppression of native Palestinians' ensuing resistance to their loss of land and struggle to achieve sovereignty.

2. I use "legitimation effects" to mean the intended or unintended tendencies of a practice to legitimate something for an audience, and "legitimation costs" as the negative impact of these effects viewed from a particular party's perspective.

3. Hereinafter Bisharat, Palestinian Lawyers. The concern of that work was to explain the West Bank legal profession's decline and marginalization during the Israeli occupation, under conditions that would seem to have afforded it significant opportunities for advance. The study was based primarily on 14 months of field research in the mid-1980s, during which I conducted about 200 interviews of some 70 West Bank working and striking lawyers. I also interviewed 15 Israeli lawyers (both Jewish and Arab), judges, human rights workers, mayors, and a variety of other community leaders and others (including clients and defendants), and observed lawyers in various work environments, including civil, military, and religious court proceedings. I also interviewed a number of Gaza-based lawyers and community leaders.

4. The agreement, negotiated in Oslo, Norway, and signed in Washington, D.C., 13 Sept. 1993, is the "Declaration of Principles on Interim Self-Government Arrangements"; I refer to it variously as the "Declaration of Principles" or the "Oslo accords." 
interests in Israeli courts have themselves been modest, these benefits nonetheless outweigh the legitimating effects of their work. Therefore, on balance, Palestinians' election to seek representation in Israeli courts, and lawyers' choice to assist them, has been justified. ${ }^{5}$

I do not, however, imagine the balancing task I undertake to be a straightforward one or my judgment of the scale's ultimate tilt to be ineluctable. In weighing what are inevitably incommensurate values, one hazards educated guesses at best-a problem to which I shall return in the Conclusion. I simply intend to load the two sides of the scale and leave it to the reader to decide whether my assessment is correct. Perhaps in doing so, I demonstrate by example how this issue may be approached in analogous societies.

I insist, though, that the appropriate question in confronting the problem here is: Was the Palestinian community under occupation advanced toward, or impeded from, its twin goals of ending Israeli military occupation and establishing some form of self-rule by lawyers' work on its behalf?

I suspect the influence of a competing, unarticulated standard on those most chary of lawyering for Palestinian interests in the Occupied Territories, and perhaps in other contexts in which lawyers' achievements fall considerably short of a community's or social movement's ultimate goals. That standard focuses on the distance between those unrealized ultimate goals and the still stubbornly unconforming reality, and deems the persistence of this gap "failure." I see no reason not to value intermediate steps that may be achieved by a social or political movement while its ultimate goals remain beyond reach.

Another credible perspective is one that acknowledges the short-term benefits rendered by lawyers to individuals suffering injustice but sees them as mere palliatives-scraps thrown from the ruler's table that keep the oppressed alive but in a state of permanent, disabling weakness. In this, the ruler plays on the classic tension between tangible, short-term, and especially individual, interests and the abstract, long-term interests of the com-

5. In urging this conclusion I imply no criticism of lawyers either in the Occupied Territories or elsewhere in analogous situations who abstain from legal practice or steer their caseloads away from political or "cause lawyering." Politically oriented law practice in the Occupied Territories can be, among other things, personally agonizing, professionally stultifying, unremunerative, and even dangerous. Some Palestinian lawyers have been subjected to prosecution, administrative detention (imprisonment without charges or trial), or deportation. See Bisharat, Palestinian Lawyers 145-46; Michael Posner, An Examination of the Detention of Human Rights Workers and Lawyers from the West Bank and Gaza and Conditions of Detention at Ketziot (Lawyers Committee for Human Rights, 1988) ("Posner, Examination of Detention"). E.g., Raji Sourani, an attorney in the Gaza Strip, was arrested in 1985 and charged with membership in the Popular Front for the Liberation of Palestine (PFLP). Part of the evidence the military prosecutor apparently relied on in bringing charges was that Sourani had defended numerous PFLP members in the military courts. The charges were eventually dropped, but Sourani was nonetheless detained administratively for a further six months. Posner, Examination of Detention 59. 
munity, confident that the individual will always respond to the immediate, urgent pangs of his own body. Relief to the individual, in this perspective, acts as a drag on the progress of the community.

This reasoning could lead to the curious proposition that more repression is better than less, at least for mobilizing a political oppositional movement. Yet more than one revolutionary movement has sought to provoke repression precisely to sharpen lines of conflict between groups and classes-and so hasten the ultimate showdown. That may, in fact, be part of the conscious strategy of the Islamic organizations now challenging the peace process in the Middle East.

I have no ready rejoinder to this view, except perhaps to note the great complexity in the relationships between elements within broad social and political movements and the fact that such movements can advance differentially along multiple fronts and in unintendedly supportive ways. Just as the threat posed by Malcolm X and the Black Panthers may have indirectly empowered the more moderate Martin Luther King and the NAACP lawyers, HAMAS and Islamic Jihad ${ }^{6}$ may have hoisted Arafat and the secular nationalists of the PLO to heights of influence they would never have scaled under their own power. This suggests that lawyers and others working within the confines of state power ought still take to the field, to reap possible benefits for the movement at large.

Israel has ruled the West Bank and Gaza Strip since 1967 through military governments established virtually simultaneously with its conquest of those regions. ${ }^{7}$ Israel has never formally asserted sovereignty there but instead has generally treated the territories as if they were subject to a belligerent occupation. ${ }^{8}$ In many respects, Israel's governing style has been highly

6. Hamas ("zeal" in Arabic but also the acronym for harakat al-muqawima al-islamiya, or "Movement for Islamic Resistance") was founded prior to the Intifada, and Islamic Jihad during it. They both seek the establishment of an Islamic state in Palestine and oppose the existence of Israel. Both groups have substantial followings in the Occupied Territories, especially in the Gaza Strip. See Ziad Abu Amr, Islamic Fundamentalism in the West Bank and Gaza (1994).

7. The military government has undergone several formal transformations over the years, most notably with the resort in 1981 to what was termed "civil administration," which amounted to little more than "an internal restructuring of the division of labor and powers within the Military Government." D. Yahav, ed., Israel, the "Intifada" and the Rule of Law 24 (1993) ("Yahav, Istael"). For more on these structural changes and their political context, see Bisharat, Palestinian Lawyers 50-56; see also id., "Attorneys for the People, Attorneys for the Land: Interests and Ideology among Palestinian Lawyers in the Israeli-Occupied Territories" (presented at Law \& Sociery Association Annual Meeting, Chicago, May 1993) ("Bisharat, 'Attorneys for the People'"); and J. Kuttab \& R. Shehadeh, Civilian Administration in the Occupied West Bank,(1980) ("Kuttab \& Shehadeh, Civilian Administration").

8. The Israeli government rejects the use of the term "Occupied Territories" in reference to the West Bank and the Gaza Strip, preferring instead the appellation "administered areas," and has declared them to be no longer considered "enemy territories." Still, its formal legal trearment of them-with the exception of Jerusalem, which it annexed and put under the jurisdiction of Israeli civilian law and courts-is as occupied territories under international law. See M. Shamgar, ed., Military Government in the Territories Administered by Israel 1967- 
legalistic, an outgrowth of Israeli commitments to democracy and the rule of law, though inflected by the special realities of occupation. ${ }^{9}$ It is this approach to governance that creates the very possibility of lawyering for Palestinian interests. ${ }^{10}$

Exclusive executive and legislative authority in the regions has rested in the hands of the military area commanders ${ }^{11}$ who, with their deputies, enjoy wide extrajudicial powers to impose deportation, house arrest, press and other censorship, administrative detention, curfews, collective punishment, house sealings and demolitions, and a variety of other sanctions. ${ }^{12}$

Together with a set of security regulations enacted in the immediate wake of occupation, these sanctions have been the principal instruments in the military governments' struggle to contain Palestinian resistance to occupation. ${ }^{13}$ Since 1967, tens of thousands of Palestinians have been tried in the Occupied Territories military courts or have been subjected to administrative sanctions. ${ }^{14}$

1980: The Legal Aspects (1982) ("Shamgar, Military Government"). Israel also prefers the names "Judea and Samaria" to refer to the West Bank, as that term is claimed to grant legitimacy to the area's annexation in 1950 by Jordan (the "East Bank").

9. There is, of course, an entirely different face to Israeli military government, the one experienced consistently by the Palestinians. From their perspective, the military government is, as I wrote in Palestinian Lawyers (at 47), "intrusive, omnipotent, capricious, and unpredictable except in its unrelenting hostility to Palestinian interests," and its law merely another in the array of weapons wielded against the Palestinian national movement.

10. While lawyers and human rights workers in the Israeli Occupied Territories have suffered occasional repression, primarily in the form of administrative detention (see Posner, Examination of Detention), they have never been assassinated or imprisoned en masse as have lawyers in Haiti, Sri Lanka, and many other states. Palestinian human rights organizations, the first of which was established in the West Bank in 1979, have, by and large, been permitted to operate, publish, and distribute their works with relative freedom.

11. Proclamation No. 2: Proclamation on Law and Administration, Art. 3(a), 7 June 1967; English trans. in Shamgar, Military Government 450-51. This order pertains to the West Bank; an equivalent order was issued for the Gaza Strip.

12. These powers are authorized under a set of Defense Emergency Regulations enacted during the British Mandate, which Israel claims were never repealed. See Yahav, Israel 45-47. This claim is refuted by Martha Moffet, Perpetual Emergency: A Legal Analysis of Israel's Use of the British Defense (Emergency) Regulations, 1945, in the Occupied Territories (1989).

13. In the West Bank, Proclamation No. 3 (the Security Provisions Order, issued within days of the conquest of the region) outlined the military courts' constitution and laws of procedure and evidence and detailed substantive security offenses. An identical, though unnumbered, order was simultaneously issued for the Gaza Strip. In 1980, amendments to the original order were consolidated in Military Order No. 378, excerpts of which are published in English in Shamgar, Military Government 476-88 ("Military Order No. 378"). This order, in turn, has been amended at least 50 times. See Amnesty International, The Military Justice System in the Occupied Territories: Detention, Interrogation, and Trial Procedures (July 1991, AI Index: MDE 15/34/91) ("Amnesty, Military Justice System"); P. Hunt, Justice? The Military Court System in the Israeli-occupied Territories (1989) ("Hunt, Justice?"); Hadar, "The Military Courts," in Shamgar, Military Government 171-216.

14. According to Israeli military sources, for 1988-93 alone, 83,321 Palestinians were tried in the military courts. Human Rights Watch/Middle East, Istael's Interrogation of Palestinians from the Occupied Territories 2 (1994) ("Human Rights Watch"). In the first two and a half years of the uprising, 9,000 administrative detention orders were issued. D. Golan, "The Military Judicial System in the West Bank," B'Tselem, Nov. 1989, at 6 ("Golan, 'Military Judicial System' "). Over 2,000 homes have been demolished or sealed in the Occupied Terri- 
There is mounting evidence as well that Israeli security personnel have been authorized for and have engaged in extrajudicial killings of Palestinian activists in the Occupied Territories. This phenomenon was first noticed during the Intifada, the uprising of Palestinian residents that swept the Occupied Territories from late 1987 to the early 1990 s. $^{15}$

Defenders of Israel's governance in the Occupied Territories have often rationalized its admittedly repressive character by citing the state of war that has existed between Israel and the Arab states and the unremitting hostility emanating from the occupied Palestinian population. ${ }^{16}$ Whether justified or not, the use of the Israeli military governments' repressive powers has been great, and its exercise frequent. ${ }^{17}$ It is therefore fitting to examine the military government in the Occupied Territories in such a symposium as this one, devoted to the dangers of legitimation in lawyering against harsh or repressive regimes.

One other feature of Israeli military government in the Occupied Territories is crucial for the topic we address here. The military government's power was never wielded solely to repress Palestinian political opposition. Other aims, such as settling Israeli civilians and protecting the Israeli economy, led the military government to take measures impinging on almost every sphere of Palestinian life. Abstention from political activity was thus no guarantee that ordinary Palestinians could avoid victimization by the military government or would have no cause to complain against it. ${ }^{18}$

Since 1967, a number of Israeli and Palestinian lawyers have defended Palestinian defendants in the Israeli military courts in the Occupied Territories. Many of these lawyers were either Jewish Israeli leftists critical of the

tories, affecting perhaps 10 times that number of occupants. Lynn Welchman, A Thousand and One Homes: Israel's Demolition and Sealing of Houses in the Occupied Palestinian Territories (1993) ("Welchman, Thousand Homes").

15. The Palestine Human Rights Information Center claimed that at least 74 Palestinians were killed by undercover Israeli units in the years 1988-91 (27 were alleged for 1992; 45 for 1993). See E. Zureik \& A. Vitullo, Extrajudicial Killings: Istael's Latest War on the Intifada (1992). Israel admits to having undercover units in the Occupied Territories but claims that they operate within standard rules of engagement that bar shootings of nonresisting arrestees. U.S. Department of State, 1993 Human Rights Report: Occupied Territories Human Rights Practices (1994) ("U.S. Dep't of State, 1993 Human Rights Report"). In the aftermath of the Tel Aviv bus bombing causing 22 Israeli deaths in October 1994, the Israeli government announced a crackdown on the Islamic groups who claimed responsibility, in the process admitting that undercover units had long operated with "kill on sight" instructions for some activists. "Rabin OKs Killing of Hamas Chiefs," Chicago Tribune, 24 Oct. 1994.

16. E.g., Yahav, Istael 16 (cited in note 7), states: "[T]he case in question involves a hostile population involved in a violent uprising against the Israeli military government and not a democratic state at peace. This being the case, if certain measures are considered 'bad law' when compared to legislation made during peacetime by civilian authorities it seems unlikely that any better law could have been found for the "hard case' at issue." See also Y. Singer, The Rule of Law in the Areas Administered by Israel (1981) ("Singer, Rule of Law").

17. Whether the justifications for Israel's conduct in the Occupied Territories are valid goes well beyond the scope of this article.

18. I describe the smothering regulation of Palestinian life in the Occupied Territories as "overcontrol" in Palestinian Lawyers (cited in note 3). 
occupation, Israeli Palestinians sympathetic to the national aspirations of the residents of the Occupied Territories, or Palestinian nationalists from the Territories themselves. ${ }^{19}$ Beginning early in 1969 , and increasingly since the 1980s, lawyers have also pressed Occupied Territories Palestinians' claims in the Israeli High Court. ${ }^{20}$

The challenge undertaken by these lawyers is a continuing one, even in the wake of the Oslo accords. As of this writing, the Palestinian Authority exercises only limited powers in Jericho and the Gaza Strip, while the greatest part of the West Bank remains under total Israeli control. Even assuming full implementation of the Declaration of Principles, the Israeli military government, and thus Israeli courts, will continue to exercise jurisdiction over a significant range of matters arising in the West Bank and Gaza Strip. ${ }^{21}$

Since the signing of the agreement, the Israeli army has continued to pursue and kill Palestinians suspected of previous violations of security regu-

19. A few lawyers practicing in the Occupied Territories represent Palestinian clients out of purely pecuniary interests. I have examined the social organization of cause lawyering within the Palestinian community in the Occupied Territories in greater depth in "Attorneys for the People" (cited in note 7). Moreover, some groups doing legal work in the Occupied Territories, such as the Association for Civil Rights in Israel, are committed to the preservation of personal liberties, not to support for Palestinian nationalism or any overtly political ideology.

20. From 1969-70 to 1986 the annual number of petitions increased from about 6 to 110. The total number for 1969-86 was 556. Ronen Shamir, "'Landmark Cases' and the Reproduction of Legitimacy: The Case of Israel's High Court of Justice," 24 Law \& Soc'y Rev. 781, 802. The extension of High Court jurisdiction to controversies arising in the Occupied Territories is discussed infra.

I do not treat advocacy on behalf of Palestinian interests in the local civil and religious court systems that predated Israeli occupation and still function intermittently and in considerably diminished form. On the civil and religious court systems in the West Bank and their problems since 1967, see my Palestinian Lawyers; J. Kuttab \& R. Shehadeh, The West Bank and the Rule of Law (1980) ("Kuttab \& Shehadeh, West Bank"); International Commission of Jurists, The Civilian Judicial System in the West Bank and Gaza: Present and Future (1994), and P. Hunt, "Some Aspects of Law and Practice in the Occupied Territories," 2 J. Refugee Stud. 152 (1989). On recent use of Israeli civil courts to vindicate claims of Palestinians in the Occupied Territories, see infra note 199 and accompanying text.

21. The Declaration of Principles (cited in note 4) provides for a Palestinian Interim Self-Government Authority to assume limited jurisdiction over the West Bank and Gaza Strip for a five-year transitional period, during which negotiations will occur on the regions' permanent starus. Among the issues specifically excepted from the jurisdiction of the Palestinian authority are "Jerusalem, settlements, military locations, and Israelis." The agreement between Israel and the PLO signed on 4 May 1994 on the Gaza Strip and Jericho area codifies even more clearly the limitations on the powers of the Palestinian Authority, e.g., clarifying for the first time that Palestinian courts-to-be will have no jurisdiction over any Israelis. While by its terms the 4 May agreement applies only to the named areas, its length (186 pages) and content suggests that it will be the template for the broader Interim Agreement that will define the powers exercised by the Palestinian Authority in the other areas from which the Israeli military withdraws. R. Shehadeh, "Questions of Jurisdiction: A Legal Analysis of the Gaza-Jericho Agreement," 92 J. Palestine Stud. 18 (Summer 1994). Israeli and Palestinian human rights and legal workers foresee a continued need for their work both in the "autonomous" areas and elsewhere, despite uncertainties over the extent and character of the Israeli courts' jurisdiction there. See Peter Ford, 'Rights Groups Explore New Roles in Palestinian Autonomy Areas," Christian Sci. Monitor, 21 June 1994. 
lations. ${ }^{22}$ Palestinians are still imprisoned or placed under house arrest without charges, ${ }^{23}$ and detainees are still subjected to torture in Israeli interrogation centers. ${ }^{24}$ Israeli settlement activities in the Occupied Territories have not fully abated. ${ }^{25}$ The military government has continued to exercise its legislative authority, issuing 105 new.military orders in the West Bank between the signing of the Declaration of Principles and mid-March $1994 .{ }^{26}$ In short, many practices that aggrieved residents of the Occupied Territories before the signing of the Declaration of Principles have continued at one level or another in its aftermath. ${ }^{27}$

There are, thus, several good reasons to examine the balance of legitimation costs and benefits of lawyering for Palestinian interests in Israeli courts. Skepticism about the efficacy of litigation for achieving social and political justice, mostly in assessments of U.S. social reform movements, has often been expressed. Some commonly voiced criticisms are that it tends to encourage a focus on the attainment of "legal rights" as ends in themselves, ${ }^{28}$ privileges lawyers with central political roles they do not deserve, ${ }^{29}$ lures movements for social and political change into trusting institutionscourts-that are structurally incapable of delivering that change, ${ }^{30}$ and entices these movements to use up scarce resources on legal battles, to the detriment of other forms of struggle. ${ }^{31}$

22. "Israelis Kill 2 Palestinian Militants during Manhunt," Los Angeles Times, 3 Oct. 1993, at A7; "Israel to Continue Hunt for Violent Activists," Fin. Times, 4 Oct. 1993, at 5; Peter Ford, "Israeli Army Stays on War Footing, Despite the Talks," Christian Sci. Monitor, I April 1994. See also note 15.

23. Lawyers Committee for Human Rights, "Fou'ad Rashad Mahmoud Shnewra and Mohammed Faraj al Ghoul-Israeli Occupied Territories," Lawyer to Lawyer Network, March 1994.

24. Human Rights Watch (cited in note 14). According to James Ron (personal comm., 7 Oct. 1994), consultant for Human Rights Watch and primary researcher for the recent report, about 400-600 Palestinians per month were interrogated September 1993-May 1994; thereafter the numbers dropped to about 200 per month. See also B'Tselem, Press Release: "One Year after the Signing of the Declaration of Principles" (13 Sept. 1994).

25. The Jerusalem-based Land and Water Establishment for Studies and Legal Services reported that between the signing of the Declaration of Principles and August 1994, Israel had confiscated or sealed off 20,000 acres in the West Bank and Gaza. Eyal Press, "Land or Peace," Nation, 22/29 Aug. 1994, at 185.

26. See Shehadeh, 92 J. Palestine Stud. at 19.

27. It is evident, however, that while the Israeli military administration's tactics are little changed from the pre-Oslo accords period, the focus of Israeli repression has shifted away from secular nationalists to Oslo accords opponents, chiefly supporters of militant Islamic organizations that have expressed their rejection of the peace plan through indiscriminate, mass violence, killing 30 Israelis, mostly civilians, in one bloody week in October 1994. Other recent Israeli measures not directly related to political repression or security, such as land seizures, are not so focused, however. See generally Tami Bash \& Shirly Eran, One Year after the Declaration of Principles: Bureacratic and Other Types of Harassment in the West Bank (Sept. 1994).

28. See, e.g., S. Scheingold, The Politics of Rights (1974).

29. S. Olson, Clients and Lawyers (1984); Bell, "Serving Two Masters: Integration Ideals and Client Interests in School Desegregation Litigation," 85 Yale L.J. 470 (1976); J. Handler, Social Movements and the Legal System (1978).

30. G. Rosenberg, The Hollow Hope (1991).

31. Id. at 31; M. McCann, Taking Reform Seriously (1986). 
The literature on this issue often takes the form of "second-guessing" of lawyers and the movements they represent (such as the U.S. civil rights movement) who have invested in a strategy of litigation. Conclusions have been drawn without benefit of a counterexample in which "movement" lawyers have foregone, or abandoned, the litigation option. In the Occupied Territories, however, we have an opportunity to test concretely the feasibility and success of one alternative to litigation attempted by lawyers-not to practice at all.

This alternative was adopted by a group of West Bank lawyers in 1967, who declared a strike against the Israeli courts that some continue to honor, in protest against the occupation. ${ }^{32}$ Doubtless there are peculiarities in that example that might prevent us from deriving broadly generalizable conclusions. Still, the West Bank lawyers' strike provides an important contrast to most other case studies of these issues.

Examination of lawyering for Palestinian interests in Israeli courts may also contribute to our understanding of the inventory of factors, and the variability of their relative weights, that lawyers and others must make in deciding whether to use litigation in the service of a social or political cause. Questions about the productivity of cause lawyering in the United States are surely challenging, and should give pause to lawyers in other societies seeking to achieve change through litigation. ${ }^{33}$

Yet the cost/benefit calculus seems likely to differ somewhat in confrontations with highly oppressive authorities, in whose courts gains may be minimal and for whom legitimacy may be an especially scarce and precious commodity. ${ }^{34}$ The margin between tangible benefits of litigation and legitimation costs in highly oppressive states may be unusually thin and the advantages of the litigation option accordingly less obvious.

It may also be that the relative importance of the various audiences among which legitimation costs must be counted varies between liberal

32. The strike was initially declared to protest the annexation of Jerusalem, other changes in the local legal structure instituted by the occupation authorities, and the perceived illegality of Israeli occupation as a whole. The strike extended to the military courts and the local civil court system, leaving the local religious courts as the only potential sites for legal practice. The strike eventually received the official endorsement and financial backing of the Jordanian Lawyers' Union, of which West Bank practitioners had been members. For more on the strike, see Bisharat, Palestinian Lawyers 145-61 (cited at note 3).

33. Perhaps not all the concerns about litigation in the U.S. are well grounded empirically. One study of U.S. lawyers working for animal rights and for gender-based pay equity found that rather than succumbing to the "myth of rights," they "deployed litigation and legal discourse resourcefully within the context of broad based movement campaigns"; McCann \& Silverstein, "The 'Lure of Litigation' and Other Myths about Movement Lawyers in the United States" 45 (delivered at Law \& Society Association annual meeting, Chicago, May 1993).

34. Do not assume that litigation in the courts of oppressive states is fruitless; an interesting point emerging from this symposium is the significantly variable records of the courts in South Africa (Ellmann), Argentina, and Brazil (Osiel). Nor is it necessarily the case that harsh regimes do not enjoy broad legitimacy. I speak only of tendencies and probabilities. 
democratic and repressive regimes. It is perhaps not entirely historical accident that, unlike many liberal democratic states, many repressive states, with tenuous legitimacy among domestic constituents, depend substantially on foreign military, economic, and diplomatic aid and have an accordingly greater stake in legitimacy within the international community. ${ }^{35}$

Likewise, fears of the negative impact of litigation on U.S. social reform movements may be less salient in highly repressive environments. For example, it is safe to say that Palestinians in the Occupied Territories have never harbored illusions that any Israeli court would ever deliver what they ultimately seek-political independence. As a result, lawyers-at least in their narrow professional roles-have seldom performed other than an ancillary function in the popular Palestinian opposition to occupation, blunting the impact of repression, limiting the damage to individual Palestinian lives and institutions. ${ }^{36}$

This essentially defensive stance may be far more typical than the U.S. model for lawyers in the deeply divided societies over which repressive states typically rule, in which lines of struggle are already starkly drawn. Hazards that lawyers will "hijack" opposition movements or that they will seriously mislead movement activists into unfounded trust of judicial institutions seem fairly remote in the kind of situation examined here. Such potential costs have never preoccupied concerned parties in the Israeli Occupied Territories, where, instead, the legitimation costs have loomed large. ${ }^{37}$

What, then, are the dilemmas confronting lawyers and movements seeking change through law under repressive regimes? ${ }^{38}$

35. Narrow popularity may often have compelled a regime to use intimidation and force as basic to its rule. Of course, dependence on foreign support is not always a function of a government's narrow domestic political legitimacy. Indeed, Israel is highly dependent on foreign assistance (see infra note 159) but enjoys broad legitimacy among its Jewish Istaeli citizens.

36. The extent of lawyers' participation in politics outside their profession is difficult to assess, as for most of the period of occupation, Palestinian political organizations have been forced underground. In the early years of occupation, a number of lawyers were prominent in organizing and heading community opposition to the Israeli presence, sometimes leading to deportation from the Occupied Territories. See Bisharat, Palestinian Lawyers 145. There is some evidence that lawyers participated in popular tribunals or committees established during the Intifada to try violators of the edicts of the Intifada organizers. Wing, "Legal Decision Making during the Palestinian Intifada: Embryonic Self-Rule," 18 Yale J. Int'l L. 95 (1993). Israeli authorities have certainly suspected some lawyers of being members of Palestinian resistance organizations. E.g., Fou'ad Shnewra and Mohammed El Ghoul, lawyers detained administratively in March 1994 and held until July, were suspected of being active in Islamic organizations. See supra note 23. Mohammed Abu Shabaan, a lawyer in Gaza, emerged after the Oslo accords as the leader of Yasser Arafat's Fatah faction in the region, before his assassination just days after the agreement was signed. Michael Parks, "Gunmen Assassinate Leader of Major Palestinian Faction in Gaza Strip," Los Angeles Times, 22 Sept. 1993, at A8.

37. Of course, all litigation has tangible costs - money and human resources. On these costs in the Occupied Territories, see infra note 103 and accompanying text.

38. A superb effort in this vein is Stephen Ellmann's study of South Africa, In a Time of Trouble (1992) ("Ellmann, Time of Trouble"). There is a voluminous literature on the role law 
Indeed, as the West Bank lawyers' strike demonstrates, the legitimacy costs of practice in Israeli courts have been periodically, and heatedly, debated by legal practitioners in the region, with palpable impact. The fragmentation of the West Bank legal profession resulting from the strike has arguably weakened not only the profession itself but also the broader community of which it is a part. ${ }^{39}$

Although the wisdom and utility of the strike are unlikely to be revisited by the West Bank legal profession as a collectivity, new law graduates there must decide whether to join the strike or begin practice. Lawyers in the West Bank, Gaza Strip, or Israel itself who oppose Israeli occupation must continue to decide whether to accept cases implicating Palestinian interests in Israeli courts. Fear that the legitimation costs had exceeded the benefits of continued legal practice during the Intifada led Felicia Langer, the most prominent Israeli lawyer working in defense of Palestinian clients, to abandon her practice in 1990. In her words:

You know, for so many years, I and people like me were cited as examples to show how liberal, how open and fair the system was: "Even Felicia Langer, with all her criticism, is operating within the system." Legitimizing the system, in a way, was the price I had to pay for operating within it (and of course, on one level, at least as regards the high court of justice, the system did have a kind of legitimacy for me, I cannot deny it). But Felicia Langer cannot operate anymore in the system. Because it is unbearable today. . . . I cannot really help anymore, I cannot change anything, but by being there I am sanctioning the system. I am acting as a fig leaf, instead of openly and explicitly condemning it. ${ }^{40}$

Local organizational agendas are also influenced by judgments about the relative costs and benefits of litigation in Israeli courts, ${ }^{41}$ as are tactical

may play in legitimating the authority of the state or political system. For a useful review of this literature and an incisive critique of Weberian models of legitimation, see Alan Hyde, "The Concept of Legitimation in the Sociology of Law," 1983 Wis. L. Rev. 379. But the writings in this area, beyond alerting us to the existence of the phenomenon of legitimation and its relations to law and legal institutions, tend to theorize so generally that they offer little guidance for the calculus I attempt here.

39. On these points, again, see Bisharat, Palestinian Lawyers 145-61.

40. "A Judicial System Where Even Kafka Would Be Lost: An Interview with Felicia Langer," 77 J. Palestine Stud. 24, 24-25, 27 (1990).

41. E.g., a Gaza-based group established during the Intifada, Palestinian Lawyers for Human Rights, apparently began by providing legal services to Palestinian defendants in the military courts but, out of despair at achieving just results in Israeli courts, switched its focus to monitoring allegations of human rights abuses. Personal communication, Human Rights Watch consultant James Ron, 4 Oct. 1994. The Palestine Human Rights Information Center (PHRIC), founded in 1986, elected from the outset to engage only in monitoring activity and abstain from any form of intervention with Israeli authorities, including litigation. In part, this grew from the group's unwillingness to recognize that Israel was in any sense a legitimate authority in the Occupied Territories. Personal communication, Peter Lems, Director, PHRIC-International, 4 Oct. 1994. 
decisions in the conduct of litigation already initiated.42 A systematic examination of the above issue thus may contribute to resolution of a series of ongoing, concrete political questions.

The next section lays a necessary factual groundwork by outlining the legal framework within which lawyers representing Palestinian residents of the Occupied Territories have practiced.

\section{THE LEGAL FRAMEWORK}

Israeli military trial courts in the Occupied Territories are of two kinds: single-judge courts, empowered to try offenses bearing punishments up to 10 years' imprisonment or petty fines; ${ }^{43}$ and three-judge courts, which try more serious offenses. The court buildings are located in Israel Defense Forces (IDF) military encampments in or on the outskirts of Palestinian towns. Many were established in former Jordanian army or police headquarters seized in 1967 and still bear the scars of battle. The courtrooms are mostly makeshift, set up in medium to large rooms, with extremely worn furniture, and often lack effective heating or air conditioning. Facilities for confidential communications between lawyers and clients near the courtrooms are almost nonexistent. ${ }^{44}$

For the first 22 years of occupation there was no formal avenue of judicial appeal from judgments of the military courts. ${ }^{45}$ However, in 1989, a military court of appeals serving both the Gaza Strip and the West Bank was

42. E.g., a number of Palestinians facing deportation from the Occupied Territories declined to pursue remedies before the Israeli High Court, or ordered their petitions withdrawn, on learning that evidence would be kept secret (see infra, text accompanying note 95). One later stated in an interview that "they [Israelis] will say afterwards that the decision was made acording to the law. And I don't want to give them this chance." Quoted in Telhami, "The Palestinian Perception of the Human Rights Issue," 13 Syracuse J. Int'l L. \&̊ Commerce 475 (1987).

43. B'Tselem, Violations of Human Rights in the Occupied Territories 1990-1991, at 7 ("B'Tselem, 'Violations"). For the first 20 years of occupation, the maximum punishment meted out by single-judge courts was five years. Military Order No. 378, Art. 50 (c)(3), at 482 (cited in note 13). The increase to 10 years was one of many alterations to the structure and functions of the military courts adopted in response to the Intifada.

44. The courts were authorized to sit anywhere in the Occupied Territories. For most of the occupation, there have been two regularly sitting courts in each of the Gaza Strip (Gaza City and Khan Younis) and the West Bank (Ramallah and Nablus). During the Intifada, additional courts were activated in Hebron, Jenin, and Tulkarm in the West Bank. Golan, "Military Judicial System". (cited in note 14). Since the Oslo accords, a single Istaeli military court has been sitting in the Gaza Strip, at the Eretz checkpoint on the border with Israel.

45. Defendants were permitted to apply to the area commander to vacate a conviction or reduce a sentence. Art. 43, Military Order 378, Art. 43 (cited in note 13). In addition, while the Israeli High Court does not function as an appellate court for the military courts of the Occupied Territories, it may issue writs of certiorari against the judgments of those courts should they err grossly or exceed their powers. Yahav, Israel 98 (cited in note 7). 
set up. Both the prosecutor and defendant may petition the court of appeals for modification of judgment or sentence. ${ }^{46}$.

Judges in all Israeli military courts are officers in the IDF, and are appointed by the area commander. ${ }^{47}$ The judges and military prosecutors both belong to the same IDF unit, that of the Military Advocate General. In practice, judges, who do not possess rights of tenure, are drawn almost exclusively from the ranks of prosecutors. ${ }^{48}$

A second system of military administrative tribunals was created early in the occupation to handle civil claims by Palestinians against the military, such as those for damages to private movable or real property caused by the IDF.49 While the jurisdiction of these "objections committees" has expanded gradually to include a broad range of issues, undoubtedly their most important category of claims are disputes over land, especially Israeli military requisitions of private property, and its assertion of state ownership over land under Palestinian control.50

Above I referred to extrajudicial sanctions employed by the occupation administration. They are "extrajudicial" in the sense that they may be imposed without formal charges and, for the most part, without resort to any judicial authority. Nonetheless, over the years, Israel has implemented avenues of recourse of greater or lesser formality for individuals subjected to some of these sanctions. Administrative detentions, for example, must now be approved and thereafter periodically reviewed by a military judge. ${ }^{51}$ As of

46. The court, which sits in Ramallah, in the West Bank, and until recently, for one day a week in Gaza, hears appeals of right from decisions of three-judge courts; defendants convicted in one-judge courts must petition for review. Amnesty, Military Justice System 16-17 (cited in note 13).

47. Some are Israeli civilian lawyers serving reserve duty with the Military Advocate General. However, only those sitting singly or as presidents of three-judge courts must be formally trained in law. The court of appeals sits in panels of either three or five, in which event two and three, respectively, must be legally trained. Id. at 16.

48. Id. at 17. There is more than simple institutional proximity between military judges and prosecutors, as one such judge stated: "In the military courts, ... the relations between the judge and the prosecutor are close, and sometimes only a thin wall divides the prosecutor's room from the judge's room. . . . Since the separation of powers is a basic principle of every legal system, its absence constitutes one of the essential reasons that the legal element in the territories is impure." B'Tselem, "Violations" at 90.

49. See Military Order No. 172, Objections Committees Order, in Shamgar, Military Government 469-72 (cited in note 8); and Military Order No. 271, Claims Order, id. at 472-76.

50. A list of matters falling within the purview of the objections committees is given in R. Shehadeh, Occupier's Law 88-89 (2d ed. 1988), and includes such matters as income or value-added tax assessments, pension rights of civil servants, customs duties, driving and business licenses, and others. On the legal methods for Israel's acquisition of land in the Occupied Territories, see Bisharat, $43 \mathrm{Am}$. U.L. Rev. (cited in note 2), and infra, text accompanying note 62.

51. The requirement of review by a military judge of administrative detentions was instituted in the Occupied Territories in 1980, generally tracking changes in Israeli legislation applicable to administrative detention within Israel itself. Among other things, the 1980 military order required that a judge review detentions within 96 hours of arrest. In March 1988 the military government abrogated that requirement and directed appeals against detention 
1989 , house demolitions may proceed only on notice to the owner, including admonition of the right to an administrative appeal to the military commander and to petition the Israeli High Court. ${ }^{52}$

Defendants in military courts are usually entitled to the assistance of counsel at trial. 53 From the outset, both Palestinian attorneys from the Occupied Territories and Israeli attorneys were authorized to appear in the military courts and objections committees. ${ }^{54}$ In the early years, few Palestinian lawyers did so, even in the Gaza Strip, where no open-ended strike was declared. 55

orders to an advisory board of military officers and authorized only to make recommendations to the military government. In apparent response to public criticism, this order was quickly rescinded. In August 1989 another order lengthened the maximum period of detention from 6 to 12 months; in December of that year, the maximum was again fixed at 6 months. Detention orders may be renewed without limit. D. Golan, Detained without Trial, B'Tselem, at 10-11 (1992) ("Golan, Detained").

52. D. Simon, "The Demolition of Homes in the Israeli Occupied Territories," 19 Yale J. Int'l L. 1 (1994). These requirements were imposed by the Israeli High Court in a case brought by the Association of Civil Rights in Israel, the Israeli counterpart to the American Civil Liberties Union. Sealings of houses were permitted withour notice in particularly urgent cases. Id. at 62. Another Israeli army home demolition practice has emerged only since 1992: the destruction of dwellings with heavy weaponry in operations to apprehend or kill wanted persons, a practice apparently adopted in response to the shooting deaths of several Israeli officers who were attempting to arrest Palestinian suspects. Needless to say, little notice is given in such cases. See B'Tselem, House Demolitions during Operations against Wanted Persons (1993).

53. However, a defendant is only entitled to court-appointed counsel in a trial for a "serious offense." Military Order 400: Defence in Military Courts Order \& 5, in Shamgar, Military Government 492-95 (cited in note 8). In practice, Palestinian defendants distrust appointed counsel and retain lawyers if they are to be represented at all, in part due to the fear that heavier fines will be imposed at sentencing to recoup the expense to the court of appointed counsel. Dugard, "Quaker East Jerusalem Legal Aid Center Program Evaluation" at 28-29 (Memorandum, 1992). The timing of the attachment of the right to counsel and actual access to imprisoned defendants are discussed infra.

54. Military legal proceedings are conducted primarily in Hebrew, although defendants are entitled to interpreters. The majority of lawyers from the Occupied Territories do not speak Hebrew and present their arguments to the court through translators. See Human Rights Watch at 252 (cited in note 14).

55. Lawyers I queried in Gaza on the topic said that it simply never occurred to them to strike like their West Bank counterparts. These responses undoubtedly had much to do with the fact that annexation of East Jerusalem, the administrative and judicial center of the West Bank under Jordanian rule, entailed significant structural transformations in the local civil court system, whereas in Gaza, no such changes were imposed. The civil courts of first instance in Jerusalem were replaced by Israeli courts, and the Court of Appeals was transferred to Ramallah, in the West Bank. See my Palestinian Lawyers 56-60 (cited in note 3). Lawyers in the West Bank were faced with the prospect of acquiescing with their feet, as it were, in the annexation of Jerusalem, had they appeared in the newly established Israeli courts or in the relocated Court of Appeals. Gaza lawyers faced no comparable quandary.

In both the Gaza Strip and the West Bank, lawyers working in the military courts have periodically resorted to short-term strikes of from one day to several months, especially in the Intifada's early years. See, e.g., Declaration of West Bank lawyers of refusal to handle cases related to the uprising, 8 Jan. 1988, 17 J. Palestine Stud. 180-81 (Spring 1988); Sherry, "Background Memorandum: Boycott of the Military Courts by West Bank and Israeli Lawyers" (Lawyers Committee for Human Rights, July 1989) ("Sherry, 'Background Memorandum' "); International Commission of Jurists, Swedish Section, The Military Legal System in the Gaza Strip and the West Bank (1993) ("ICJ Swedish Section, Military Legal System"); and Rishmawi, 
In the West Bank, the military government responded to the legal profession's boycott by authorizing Israeli lawyers to appear in the local civil courts of the region (Israeli lawyers, it will be recalled, had appeared in the military courts from the outset). ${ }^{56}$ By the early to mid-1970s, however, a number of Palestinian advocates had entered military court practice in both regions, those in the West Bank suffering castigation by their still striking colleagues.

The Supreme Court of Israel sits in two capacities. It is, first, the highest appellate court in Israel, reviewing criminal and civil judgments of all the district courts within the country. In its capacity as a High Court of Justice, the Israeli Supreme Court exercises original jurisdiction over petitions charging Israeli government functionaries acting in their official capacities with abusing or exceeding their powers. The court has come to consider petitions from residents of the Occupied Territories in this second capacity. ${ }^{57}$

It is of paramount relevance that Israel has never adopted a constitution and cleaves to the principle of parliamentary supremacy-that is, its High Court does not enjoy powers of review of Knesset legislation. ${ }^{58}$ Paradoxically, the absence of a constitution or bill of rights has thrust the Court into its now well-established role as the principal guarantor of individual civil liberties and has contributed to the Court's elevated standing in the Israeli public view. 59

"The Lawyers Strike in Gaza," 21 Centre for the Independence of Judges \& Lawyers Bull. 23-25 (1988).

56. A civil court magistrate in Hebron held this order invalid in 1967 and refused to permit the appearance of an Israeli lawyer. His decision was reversed by the civil Court of Appeals, which broadly upheld the legislative authority of the military Area Commander. See Institute for Legislative Research \& Comparative Law, Law and Courts in the Israel-held Areas (1970). It is in large part due to this decision that the civil court system in the West Bank never became a bastion for legal struggle against the occupation.

57. Nathan, "The Power of Supervision of the High Court of Justice over Military Govemment," in Shamgar, Military Government 109-70 (cited in note 8) ("Nathan 'Power of Supervision' "). The theory that the High Court exercises what is in effect personal jurisdiction over its government officials operating in the Occupied Territories is admittedly tenuous but, as a matter of policy, has never been challenged by state attorneys. For the moral and pragmatic reasons for this policy, see Negbi, "The Israeli Supreme Court and the Occupied Territories," 27 Jerusalem Q. 33 (1983).

58. See Martin Edelman, Courts, Politics, and Culture in Israel (1994) ("Edelman, Courts"); and Daniel Elazar, ed., Constitutionalism: the Israeli and American Experiences (1990). However, quasi-constitutional adjudication has developed through the Knesset's piecemeal enactment of a series of Basic Laws that have the status of "primary legislation"- -superior, in still to be adequately defined ways, to standard Knesset legislation. Edelman, Courts.

59. Edelman, Courts. The courts in Israel are second only to the military among state institutions in gaining the public's trust; in polls taken in 1987, $73 \%$ of Jewish Israelis had "a great deal of confidence" in the military, while $52 \%$ expressed the same trust in the courts. Only $4.9 \%$ gave this assessment of the government, and the highest percentage achieved by any single political party (Labor) was $12.6 \%$. Palestinians living in Israel as citizens shared this view of courts, although to a lesser degree (39.6\%). Simon, Landis, \& Amir, "Jewish and Arab Perceptions of Civil Rights in Israel," 10 Stud. L., Politics, \& Soc'y 245 (1990). These distributions were similar to other polls conducted at the same time and earler and are corroborated 
Military government actions in the West Bank and Gaza strip are reviewed against the requirements of the international laws of belligerent occupation and the principles of Israeli administrative law..$^{60}$ Although Israel is a signatory of the Fourth Geneva Conventions of 1949, the High Court has held its provisions to be constitutive, not merely declarative of international law, and therefore nonjusticiable in Israeli municipal courts in the absence of national legislation adopting it. ${ }^{61}$ On the other hand, customary international law, including its codifications in the Hague Conventions of 1907, is incorporated into Israeli law without enabling legislation. ${ }^{62}$

The procedure for filing a petition before the Israeli High Court is relatively simple, rapid, and inexpensive. An aggrieved party may petition a single justice for a temporary order (or order nisi). If a prima facie basis for the petition is found, the order is granted, and the respondent is required to file a brief and appear in court before a panel of justices to show cause why they should desist from, or perform, a certain act. This is usually done within 30 days of the issuance of the order nisi. ${ }^{63}$ Both general policies of the military government and its specific administrative acts have been challenged by Palestinian petitioners.

Unlike the military courts of the Occupied Territories, all High Court proceedings are conducted solely in Hebrew, and lawyers appearing before the court are required to be members of the Israeli bar. Lawyers from the Occupied Territories have thus been institutionally barred from representing clients before the High Court. To the extent they are involved at all in High Court practice, they are limited to identifying controversies appropriate for petitions, referring cases to Israeli lawyers, and working in support of them in case preparation. ${ }^{64}$

more recently by Zureik, Moughrabi, \& Sacco, "Perception of Legal Inequality in Deeply Divided Societies: The Case of Israel," 25 In'l J. Middle East Stud. 423 (1993).

60. Yahav, Israel 64-74 (cited in note 7), provides several examples in which Israeli administrative law has imposed tighter restrictions on the military government than those called for by international law.

61. This holding was reached in a celebrated dispute over the military government's requisitioning of land in the West Bank in 1978 for purposes of Israeli civilian settlement, the Beit El-Toubas case. See Bisharat, $43 \mathrm{Am}$ U.L. Rev. (cited in note 1).

62. Unofficial English Translation of HCJ 606/78 and 610/78 (the Beit El-Toubas case).

63. Cohen, "Justice for Occupied Territory? The Israeli High Court of Justice Paradigm," 24 Colum. J. Transnat'l L. 471, 480-81 (1986).

64. Palestinian lawyers who reside in the annexed portions of Jerusalem are entitled to membership in the Israeli bar. Only in the past several years have a handful exercised this right. The lawyers' long reticence reflected their concern that joining the Israeli bar would acknowledge the permanency, if not the legitimacy, of the annexation of Jerusalem. See Bisharat, Palestinian Lawyers 74. 


\section{MILITARY COURT PRACTICE}

To what extent are lawyers operating in the military courts and tribunals in the Occupied Territories able to defend the interests of their Palestinian clients? If the subjective judgment of these lawyers is to be trusted, then the answer is clearly: very little. Most lawyers feel that the military court system is so skewed against defendants as to leave virtually no scope for lawyerly action. In the words of prominent West Bank attorney Jonathan Kuttab: "Many top West Bank lawyers refuse to practice before the military courts. I hate myself and question my integrity as a lawyer when I appear in the military court. I tell myself that I am a social worker and not a lawyer, bringing cigarettes to my client." 65 One need not search hard to identify the causes of this pessimism. Perhaps the single most important area of defect in the military courts lies in their laws of procedure and policies governing pretrial detention of defendants.

Israeli soldiers are permitted to arrest any person without a warrant upon suspicion of having committed a security offense. ${ }^{66}$ Given the laxity of this standard, challenges to the legality of arrests are virtually pointless. ${ }^{67}$ Until 1992, military authorities were permitted to hold a detainee incommunicado and without charge or judicial scrutiny for up to 18 days; that period was reduced for juveniles and defendants accused of minor offenses to 8 days. ${ }^{68}$ Judicial approval is required for detention beyond this period; if the prosecution seeks this through an "extension hearing," the court may order the suspect held for up to 6 months without charge. ${ }^{69}$.

65. Quoted in Sherry, "Background Memorandum" at 17 (cited in note 55). I recorded similar sentiments repeatedly during my field work in the region. Bisharat, Palestinian Lawyers 138-43 (cited in note 3).

66. Military Order No. 378, Art. 78(a), at 483 (cited in note 13).

67. The laws of procedure of the military courts do not explicitly provide for writs of habeas corpus, although a provision for "miscellaneous applications" allows in principle for release of a prisoner on the grounds that the arrest was illegal or unnecessary. However, such requests "appear to be invariably treated by the military courts as requests for release on bail. In practice, therefore, there is no habeas corpus remedy available to detainees in the Occupied Territories." Amnesty, Military Justice System 27 (cited in note 13). Soldiers are also empowered to perform searches of homes and institutions without a warrant, although authorization by an officer of the rank of lieutenant colonel is required prior to entry. Country Reports on Human Rights Practices for 1991, "Israel and the Occupied Territories", U.S. Department of State, in $21 \mathrm{~J}$. Palestine Stud. 114, 118 (1992) ("Country Reports"). Challenges to such searches and to any evidence they may uncover are almost nonexistent.

68. Under pre-1992 law, suspects could be detained initially without warrant for 4 days, after a warrant from a police officer for a further 7 days, and after a second warrant from a police officer of higher rank for a final 7-day period. Military Order No. 378, Art. 78(c), (d), and (e), at 483. Many continue to be held for the full 18 day period. Human Rights Watch at 103 (cited in note 14).

69. Military Order No. 378, Art. 78(f). Human Rights Watch (at 104) describes the extension hearing as "a perfunctory affair, in which the judge almost always approves the interrogators' request for extending the detention, despite the absence of formal charges." 
Once charges are filed, the defendant may be further held until termination of trial proceedings. ${ }^{70}$ Bail in security cases is almost entirely theoretical. ${ }^{71}$ There is no statutory or other recognition of a defendant's right to a speedy trial. During the Intifada, first trial dates were often set three months after arrest, with postponements due to failures to produce defendants or prosecution witnesses leading to much lengthier detentions, sometimes exceeding a year. ${ }^{72}$

As mentioned above, defendants in military courts are entitled to legal counsel. In 1988, apparently in response to repeated criticisms of its pretrial detention practices, the military government issued an order establishing the right of a detainee to consult a lawyer on request "as quickly as possible" and requiring authorities to contact the lawyer and next of kin of the detainee's location. ${ }^{73}$ However, the decree also empowered police officers to delay by written order an attorney visit up to 15 days when necessary for local security or "if the good of the investigation demands it." Other provisions of the same decree permit judges to quash notifications of arrests for up to 8 days and, in some circumstances, to order delays in attorney visits up to 90 days.

These purported reforms apparently did little to alter circumstances on the ground. As late as 1993, the military government's notification procedures were still largely neglected or ineffective. ${ }^{74}$ Attorneys were regularly barred from seeing clients, often without written order, in excess of 20 days, and almost always until "investigation" in the case-meaning, in effect, interrogation of the defendant-was completed. ${ }^{75}$

70. Military Order No. 378, Art. $78(\mathrm{~g})$.

71. The right to bail is assured in Military Order No. 378, Art. 79(a), at 484. Meaningful statistics on bail in the military courts are hard to come by, but attorneys assert that pretrial release is almost never granted. See, e.g., Sherry, "Background memorandum" at 26-28. According to B'Tselem monitors: "During our observations in court, it became clear that detention is perceived by all parties in the legal system as a means of punishment and that denial of release on bail is an accepted norm in the territories." Golan, "Military Judicial System" at 33 (cited in note 14). The probability of release on bail was even further slimmed by procedures adopted temporarily during the Intifada that required only in camera review of written motions, with neither defendant nor defense attomey present. Id.

72. Sherry, "Background Memorandum" at 28-29.

73. Excerpts from the order, Military Order No. 1220 in the West Bank, appear as an appendix to Sherry, id. at 32-35, and form the basis for my discussion here. The requirement of notice to the attorney and next of kin was a response to lawyers' recurrent inability to locate clients among the various prisons and detention facilities maintained by Israel. This problem became particularly acute during the Intifada but existed at least by the mid-1980s, if not before.

74. Army directives issued in the wake of Military Order No. 1220 stipulated that detainees fill out postcards upon incarceration that would be sent to their families and that lists of detainees be posted in publicly accessible areas and updated daily. Sherry, "Background Memorandum" at 4-5.

75. Hicks, "A Continuing Cause for Concern: The Military Justice System of the Israelioccupied Territories" 3-4 (Lawyers Committee for Human Rights, Feb. 1993) ("Hicks, 'Continuing Cause'"). 
Lawyers engaged in military court practice claim that the overwhelming majority of defendants are brought to court with formal charges only when their interrogation yields an inculpatory statement. ${ }^{76}$ These statements are typically reduced to writing in Hebrew, a language neither spoken nor read by most Palestinians in the Occupied Territories, and signed by the defendant.

For many years lawyers for Palestinian defendants have claimed that their clients' confessions had been coerced by psychological and physical abuse, often including severe beatings both by IDF and General Security Services (GSS) personnel. ${ }^{77}$ These claims were corroborated by a number of outside agencies and sources. With equal consistency, the claims were denied by the Israeli government. ${ }^{78}$

In 1987, the Israeli government was prompted to establish a Commission of Inquiry into the Methods of Investigation of the General Security Service Regarding Hostile Terrorist Activity, headed by former Israeli Supreme Court Justice Moshe Landau. ${ }^{79}$ The Landau Commission found that for 16 years, GSS interrogators had regularly employed psychological and physical "pressures" against Palestinian detainees and then lied in closed hearings in military courts, in the attempt to conceal these methods and to ensure convictions. The commission censured the GSS for its record of perjury but rationalized the use of "moderate physical pressures" as a necessity in the war against "terrorism." In an unpublished portion of its report, the commission issued guidelines for the application of force during

76. According to a B'Tselem study, practitioners estimate that confessions are obtained in $80 \%$ or more of cases in the military courts. B'Tselem, "Violations" at 93 (cited in note 43). Reports I gathered in the field suggested that this estimate is conservative. In the words of the former chief military prosecutor in Gaza: "As someone who is very familiar with both sides of the story, as a prosecutor and a lawyer, I have difficulty remembering one person accused of terrorist actitivity who was acquitted. There are almost no such instances. Every person who is accused is found guilty. Sometimes on the basis of criteria which no Israeli court of law would accept. In $99 \%$ of the cases the accused come to court with a signed confession of guilt. That's suspicious." Quoted in Sherry, "Background Memorandum" at 7.

77. The General Security Service, sometimes referred to by its Hebrew initials "Shin Beit," is Israel's main domestic intelligence and security agency.

78. Amnesty International issued its first report on ill treatment of Palestinian detainees in Israeli prisons in 1970 and repeated its concerns about such allegations in its Annual Reports through the 1970 s. In the late 1970 s, a number of nongovernmental organizations, including the Swiss League for Human Rights, Pax Romana (an international association of Catholic jurists), and the American National Lawyers' Guild, publicized allegations of torture in the Occupied Territories. The London Sunday Trmes also published a widely read series on the controversy in 1977. See Amnesty International, Report and Recommendations of an Amnesty International Mission to the Government of the State of Israel (1979).

79. The move was precipitated by two major embarassments to the government. In the Nafsu case, it came to light that a Circassian officer of the GSS had been convicted of espionage on the bases of a coerced confession and perjured testimony by several of his fellow officers. In the Bus 300 incident, a Palestinian who participated in the hijacking of an Israeli civilian bus on the coastal highway was revealed to have been beaten to death after his apprehension at the direction of the head of the GSS, in the wake of government statements to the press that all the hijackers had perished in a gun battle. 
interrogations. ${ }^{80}$ In August 1993, the Israeli Supreme Court rejected a petition challenging these guidelines and seeking their publication, holding the petition too factually vague to be justiciable. ${ }^{81}$

There can now be no serious doubt that nonlethal physical abuse of Palestinian detainees by Israeli soldiers and police interrogators is routine and systematic. According the most recent detailed study of the issue by Human Rights Watch:

The overriding strategy of Israel's interrogation agencies in getting uncooperative detainees to talk is to subject them to a coordinated, rigid, and increasingly painful regime of physical constraints and psychological pressures over days and very often for three or four weeks. ... The methods used in nearly all interrogations are prolonged sleep deprivation, prolonged sight deprivation using blindfolds or tight-fitting hoods; forced, prolonged maintenance of body positions that grow increasingly painful, and verbal threats and insults. ${ }^{82}$

Cases of severe, even fatal, physical abuse, while not nearly as common, have also been documented. ${ }^{83}$ There has also been a discernible shift in interrogation practices since the Landau Commission Report, which Human Rights Watch refers to as the "bureaucratization of torture." The trend, especially since 1991, has been "toward increasing standardization of methods . . . calibrated combinations of psychological and physical measures, combined with a more restrictive policy toward beating"84 and toward "low visibility" abuse. I shall return to this shift later.

80. The commission noted the difficulty investigators faced in obtaining intelligence and evidence to support convictions for charged offenses from a steadfastly uncooperative Palestinian population. Excerpts of the Landau Commission report were published in English in Jerusalem Post, 1 Nov. 1987.

81. E. Gordon, "Petition against GSS Rejected," Jerusalem Post, 13 Aug. 1993. The petition was brought by an individual Palestinian, who alleged that he had been tortured in custody, and the Public Committee against Torture in Israel.

82. Human Rights Watch at $x$ (cited in note 14). See also Amnesty International, Istael and the Occupied Territories: Fear of Torture or Ill-Treatment, March 1992; AI Index: MDE 15/ 05/92, at 2-3; and U.S. Dep't of State, 1993 Human Rights Report (cited in note 15).

83. See, e.g., Ginbar \& Bash, "The Death of Mustafa Barakat in the Interrogation Wing of the Tulkarm Prison," B'Tselem, Sept. 1992. Another study by the Public Committee against Torture in Israel estimated that in the first three years of the Intifada, of 8,000 Palestinians interrogated by army or GSS agents, at least a quarter were subjected to "intensive methods" and that in 1988-89, 18 Palestinians died in detention, 5 from interrogation. Cohen, "Talking about Torture in Israel," 6 Tikkun, Nov./Dec. 1991, at 23, 26. While such incidents have on occasion led to criminal prosecutions of responsible parties, punishments are typically light. Iyad Aql, 17, died after a punitive beating by members of the Givati Brigade of the IDF in February 1988. In 1989, one soldier was sentenced to two months' imprisonment and three others received suspended sentences up to five months. Amnesty, Military Justice System 46 (cited in note 13).

84. Human Rights Watch at 55. This trend is more evident in questionings performed by the GSS. Beatings, though less severe than before, are still the prevailing norm in IDF interrogations. Cf. Yuval Ginbar, The "New Procedure" in GSS Interrogations: The Case of "Abd A-Nasser 'Ubeid (Nov. 1993). 
Procedural rules in the military courts require a "mini-trial," or "trial within a trial," on the admissibility of a statement challenged as involuntary. Military prosecutors are required only to establish that the interrogation methods applied were not "degrading" or violations of "basic accepted values" and that the defendant was not deprived of his free choice at the moment the statement was signed. ${ }^{85}$ In what should by now be a familiar refrain, practitioners report that, in their experience, mini-trials almost never result in a finding that a confession was involuntary and often merely cause delays, a tougher prosecutorial stance in subsequent plea bargaining, and still less sympathy at sentencing by the judge. ${ }^{86}$ Evidentiary rules require corroboration of a defendant's statement, but the "something else" may be as little as the actual existence of a person, place, or event included in the statement or even the defendant's failure to deny culpability for offenses at the extension of detention hearing. ${ }^{87}$

The upshot of these procedures is that defendants are usually delivered to court, trussed, as it were, and ready for conviction. Facing daunting odds at trial and the prospect of pretrial detention that, for most offenses, promises to exceed the length of sentence, the rational course for nearly all defendants is to seek a negotatiated disposition minimizing penalty. Indeed, lawyers working in the military courts report that their representation consists almost exclusively of plea bargaining, one describing his role as being a "broker of prisoners' files." 88

85. There is some evidence that Israeli military judges are privy to the otherwise secret GSS guidelines for interrogation. E.g., use of such techniques as prolonged sleep deprivation and body position abuse has been openly admitted in court by GSS interrogators, without prompting the court to suppress the statements so gained. The inquiry of a trial observer into the admissiblity of such statements met with this cryptic response from a military court judge: "Some things are permitted, you know." Human Rights Watch at 254.

The apparent inability of military court judges over 16 years to detect instances of coercive interrogation documented by the Landau Commission suggests that violations of current interrogation guidelines may also go undetected. Some judges may be simply indifferent to whether Palestinian detainees are physically abused. An Amnesty International observer witnessed a Palestinian youth being brought into the military court in Hebron displaying obvious injuries. The youth began shouting that a soldier seated in court had beaten him during arrest. The presiding judge told the youth that his tale was irrelevant and asked him if he wanted to get his case over with that day. The youth entered his guilty plea and was sentenced with no further ado. Amnesty, Military Justice System 69-70.

86. Id. at 68.

87. Hunt, Justice? 29-30 (cited in note 13). Under a 1979 amendment to the Israeli evidence code (which is followed in the military courts of the Occupied Territories), a conviction may be founded on an out-of-court statement of third parties, whether or not the declarant is brought to court or later recants. Amnesty, Military Justice System 68.

88. Quoted in Hicks, "Lawyers and the Military Justice System of the Israeli Occupied Territories" at 12 (Lawyers Committee for Human Rights, May 1992) ("Hicks, 'Lawyers' "). Yahav, Istael 93 (cited in note 7), claims that during the Intifada, defendants refused en masse to plead guilty, compelling the military court to try a far greater number of cases than ever before. This phenomenon was probably localized among detainees awaiting trial in one or two prisons but did not spread or persist beyond a brief period. In fact, it appears that Palestinian political organizations never developed a coordinated strategy or schooled their membership in how to handle decisions in their court cases, leaving them instead to their own devices. 
Under the circumstances, it is not surprising that few practicing lawyers reported ever having recorded an acquittal. The situation may have changed slightly for the better during the Intifada, when repeated failures by prosecutors to produce witnesses at trial resulted in some dismissals. ${ }^{89}$ Still, Israeli military goverment officials agree that the rate of conviction in the military courts runs to $95 \%$ or higher. ${ }^{90}$ Statistics provided by the IDF to Human Rights Watch show that of the 83,321 Palestinians tried in the military courts between 1988 and 1993, 2,731, or 3.2\%, were acquitted.91

One would think the opening of the military court of appeals in April 1989 augured well for the rights of Palestinian defendants. Indeed, the absence of such a court had been a frequent complaint of local lawyers. Not so, however:

In practice the Court of Appeal has proved to be of little practical benefit to the lawyers and actually harmful to their clients. The most commonly voiced complaint was that the Court of Appeal, through allowing the prosecution the right to appeal, had enabled the authorities to impose higher sentences in a more uniform manner. Lawyers felt that the small victories they were sometimes able to gain from more lenient judges or as a result of prosecutorial error in the trial courts were now likely to be taken away from them at the appeal stage. ${ }^{92}$

One Palestinian lawyer reported having lodged 25 petitions on behalf of clients in the court of appeals, prevailing on none of them, and contesting 50 petitions by the prosecution, losing 48.93 Ironically, some lawyers felt compelled to boycott the very court whose establishment they had earlier demanded. ${ }^{94}$

Appeals against administrative sanctions, whether to military judges or to objections committees, have most often been fruitless. Challenges to administrative detentions are hampered by the military judges' reliance on "secret evidence"-evidence supplied to it ex parte by the prosecution and

89. It was apparently not unusual for prosecution witnesses to fail to appear for four or five trial settings. Most prosecution witnesses are Israeli soldiers, many of whom are reservists. Upon completion of their service, they retum to their homes in Israel and thereafter refuse to travel to the Occupied Territories to testify. Sanctions, such as dismissal, were far less common than the court's offer of an "discounted" plea bargain. Golan, "Military Judicial System" at 31 (cited in note 13).

90. Hicks, "Lawyers" at 12.

91. Human Rights Watch at 2. Figures provided to the Israeli organization B'Tselem by the Israeli government showed that from the beginning of the uprising to November 1989 , some 10,000 persons were convicted of charges of disturbing the peace, while 400 were acquitted of the same charge. B'Tselem, "Violations" at 53 (cited in note 43). Generally speaking, the military government has been less than forthcoming with consistent, reliable statistical data on the functioning the military court system. See Hicks, "Lawyers" at 12, and Hicks, "Continuing Cause" at 3 (cited in note 75).

92. Hicks, "Lawyers" at 14-15.

93. Id.

94. Golan, "Military Justice System" at 42 n.15. 
never revealed either to the defendant or to defense counsel. ${ }^{95}$ Objections committees, empowered by statute to adopt their own rules of procedure and evidence, operated until 1984 without promulgating any such rules, and a further two years elapsed before the rules were published. 96

Lawyers maintain that the Israeli authorities exploited the lack of procedural and evidentiary guidelines in the objections committees to foil their clients' claims. This was particularly strongly felt in reference to the military government's assertion of control over lands claimed by Palestinians as their own. The objections committees, for example, have rejected property tax receipts proffered by Palestinians as proof of ownership. Needless to say, attorneys were deeply embittered by the willingness of the Israeli authorities to recognize ownership for purposes of tax collection but to contest it in upholding an expropriation decree. ${ }^{97}$ Victories were not unattainable, however, in some claims for damages against the Israeli military that involved no political or security dimension.98

If the tangible benefits of legal struggle in Israeli military courts are, from the Palestinian perspective, rather insubstantial, they are not altogether nonexistent. For example, lawyers are permitted to visit detainees before their families are able to and thus often function as links between defendants and the outside world. ${ }^{99}$ They provide moral support to prisoners

95. Golan, Detained (cited in note 51); Posner, Examination of Detention 9 (cited in note 5). However, Israeli military authorities claimed that in 1991, some $30 \%$ of appeals resulted in reductions or reversals of detention orders. Country Reports at 117 (cited in note 67). (1991).

96. E. Benvenisti, Legal Dualism: The Absorption of the Occupied Territories into Istael 45

97. On the process of Israeli acquisition of Palestinian lands both in Israel and the Occupied Territories, see Bisharat, 43 Am. U. L. Rev. (cited in note 1).

98. Palestinian attorney Raja Shehadeh recounts a successful claim for negligence against an Israeli military hospital in his review of Yahav's Israel, the "Intifada," and the Rule of Law, "Apologia for Occupation," 23 J. Palestine Stud. 104-7 (1994). He points to a different problem, however, relating that, eight years after the claim's grant, his client had yet to receive the award. This recalls repeated complaints I heard that the military government, while orderly and efficient in its deployment of repression, was lethargic at best in service to Palestinian needs. Moreover, there is a major problem of ineffective or nonenforcement of laws and court judgments, including even those of the High Court. Lawyers complain of a parallel failure of the military government to actually implement policies that it claims to have adopted-usually promised reforms. For an example of the latter, see supra notes 74 and 75 and accompanying text. For two examples of the military government's failure to abide by procedures mandated by High Court rulings, see infra notes 110 and 111 . Numerous other examples could be cited.

99. For a number of years, Israel has permitted representatives of the International Red Cross to visit and examine detainees in the Occupied Territories after 14 days from their arrest. This access can be denied in exceptional circumstances. The global policy of the ICRC is not to publicize its findings but to report them confidentially to the host government. This policy was broken in 1992, when an ICRC press release revealed that the organization's numerous reports and recommendations to the lstaeli government had been routinely ignored. Saul Friedman, "Israel Draws Rare Red Cross Rebuke," Newsday, 22 May 1992. Complaints to the Israeli government were again made public by the ICRC in 1993. Associated Press, "Red Cross: Israel Denies Basic Rights," 24 May 1993. 
(and are sometimes allowed to take them food and clothing) and information to distraught families about the condition of their loved ones.

These services may not provide lawyers with professional stimulation or the sense that they are employing their specialized legal knowledge and training-many join Jonathan Kuttab's denunciation of practice in the military courts as a form of "social work." But it is equally true that the services are, nonetheless, crucial to defendants and to the broader community. Further, the lawyers' unique privilege of access to the incarcerated, a direct function of their professional relationships with clients, is what makes delivery of the services possible. The value of lawyers' contacts with imprisoned defendants is vividly evident in the testimony of Felicia Langer:

I am sure that I gave them love and compassion and understanding at very important moments of their lives. . . . Once there was a client of mine, Suleiman Najab, who almost died under torture. I saw him afterwards. The sight was ... horrible. And he told me later that what kept him going was his belief that they could not kill him, because they knew that I was there and that my friends were there. ${ }^{100}$

Bail hearings, though seldom successful in gaining the release of defendants, afford another opportunity for lawyers to give detainees momentary respite from interrogation, to offer them brief advice, and to check on their physical condition. These hearings also provide the defense an early opportunity to retract a confession, complain of abuse or other improper means, or deny an accusation. The potential evidentiary implications of such actions are subtleties that surely escape the majority of detainees, especially if they are suffering sleep deprivation and other disorienting abuses common during interrogation. ${ }^{101}$

It also seems probable that lawyers under many circumstances are able to secure more favorable dispositions in plea bargaining than would unrepresented defendants. For example, mini-trials on the admissibility of statements, while, like bail hearings, are almost always unavailing, are viewed by local lawyers as highly effective tools in gaining plea-bargaining leverage. ${ }^{102}$

100. Langer, $77 \mathrm{~J}$. Palestine Stud. at 35 (cited in note 40).

101. Hunt, Justice? at 17-18 (cited in note 13). Human Rights Watch at 105 (cited in note 14) reports that in extension of detention hearings (which differ from bail hearings), in practice often conducted in the absence of counsel and in small, nondescript rooms adjacent to interrogation centers, some detainees are unaware that they are not still being interrogated.

102. It is not clear why this is the case, although fear of the defense prevailing cannot be the explanation. It may be the use of time and manpower or reluctance that interrogation techniques be made public that causes military prosecutors' amenability to favorable plea terms at mini-trials. Human Rights Watch at 262-63. It suggests, though, that if there are always tangible costs to litigation for social movements (see note 103), tangible costs are also being imposed on the state, forcing it to recalculate its interests in the case. Lawyers, I submit, know better how to run up the state's meter than the unrepresented. In some, even many, cases this may result in the state's retreat from its original objective and effective protection for the claimant-defendant. 
Again, this effective tactical use of mini-trials is probably beyond the ken of most Palestinian detainees.

It seems indisputable, then, that lawyers working in the military courts have offered vital services to individual activists and their families, diminishing both the length of prison terms and the severity of suffering entailed. Though the record of lawyers' struggles in the military legal system in the Occupied Territories does not glitter with overt success, and these lawyers' contribution to the political movement to end Israeli occupation defies quantification, it is no less solid and real. Defendants themselves have consistently sought the assistance of lawyers in the military courts, one very important index that legal representation is not without substantial yield, at a minimum, to them as individuals. ${ }^{103}$

\section{THE RECORD OF THE ISRAELI HIGH COURT}

If the experience of lawyers attempting to defend Palestinian defendants in the military courts is relatively discouraging, the record of the Israeli High Court in its treatment of petitions from the Occupied Territories is somewhat more mixed and complicated. On the one hand, the High Court has never overturned a policy of the military government as a violation of The Hague Convention. This stems in part from the Court's oft-avowed reluctance to intervene in what it regards to be political and security matters and the expansive view it has taken of military necessity, comprehending both tactical and strategic considerations. ${ }^{104}$

A partial list of military government policies upheld by the court provided by Israeli lawyer Dan Simon includes imposition of prolonged curfews; requisition of private property for military bases and civilian settlements;

103. Lawyers' fees for representation in the military legal system in the mid-1980s ranged between 150 and 500 Jordanian dinars (about $\$ U . S .450$ to $\$ U . S .1,500$ at then prevailing exchange rates). These rates must be considered in relation to 1992 per capita incomes of $\$ 1,800$ in the West Bank and $\$ 590$ in the Gaza Strip. See CIA World Factbook (1992 ed.). During the late 1970s and early 1980s, families of defendants in the military courts were able to gain reimbursement for legal fees from a joint Jordanian-PLO committee distributing the "Steadfastness Fund" established by the Arab states. An American Friends Service Committee legal aid office in East Jerusalem subsidized about 500-600 military court cases annually, for many years paying half the attorney's fee. During the Intifada, a number of groups, including the Gaza Bar Association, organized a pro bono service for military court defendants that alleviated expenses for at least some. ICJ Swedish Section, Military Legal System (cited in note 55). However, for most of the period of occupation, those Palestinian defendants who have retained counsel have paid lawyers from their own assets. The most politically active sectors of Palestinian society, and those suffering the most repression (in the form of arrests, administrative detentions, home demolitions and sealings-not to mention deaths and woundings) have tended to be the poorest. See, e.g., Kuttab, "A Profile of the Stonethrowers," 17 J. Palestine Stud. 14 (1988); and Zureik, Graff, \& Ohan, "Two Years of the Intifada: A Statistical Profile of Palestinian Victims," 12 Third World Q. 97 (1990-91). Lawyers' complaints over nonpayment were also not uncommon.

104. Cohen, 24 Colum. J. Transnat'l L. (cited in note 63). 
restrictions on international telephone communications; indefinite suspension of elections for local councils; taking temporary possession of private property for military purposes; strict limitations on burial ceremonies of people killed in clashes with security forces; deportations; conditioning the right to travel on special and easily revocable permits; limiting duration of stays abroad and, upon default, indefinitely suspending the right to return; routine use of administrative detentions; refusal to allow unification of families where one of the spouses has no right of residency; censorship on press and publications; imposition of a value-added tax on residents of the Occupied Territories; home demolitions and sealings; indefinite closure of schools, universities, trade unions, and social clubs. ${ }^{105}$

It also appears that unsuccessful challenges to some practices may have emboldened the military governments by eliminating qualms as to the legality, and perhaps morality, of the practices upheld. Prior to 1979 , for example, residents of the Occupied Territories who had reason to fear they were in line for a home demolition or sealing - which, until that time, were executed without notice to the occupants-would file anticipatory petitions for relief in the High Court. ${ }^{106}$ Likely out of fear of High Court censure, the military government often denied its intent to destroy or seal the home. In 1979, the High Court rejected the first petition seeking to reverse a home sealing, untethering the military government and ratifying the destruction of hundreds of homes over the next 10 years. In Simon's opinion, "This attitude [of the High Court] allowed the practice to proliferate. The Court's legitimization and institutionalization of the practice transformed it into a routine, almost mundane exercise of legal power."107

On the other hand, the High Court has been somewhat more gracious in awarding procedural rights to Palestinian petitioners in their interactions with military authority. For example, it was at the Court's insistence, in a later phase of its jurisprudence on home demolitions, that Palestinians whose dwellings were targeted were granted rights of appeal prior to the execution of the demolition order. ${ }^{108}$ Deportees are guaranteed the right to attend an administrative hearing prior to their deportation. ${ }^{109}$ Although the

105. Simon, 19 Yale J. Int'l L. at 23 (cited in note 52).

106. Such petitions were filed when atypical notice was given, when a family member was accused of a grave offense and demolition seemed a likely sanction, or sometimes when soldiers appeared early to photograph or measure the home in preparation for its demolition. Welchman, Thousand Homes at 65 (cired in note 14).

107. Simon, 19 Yale J. Int'l L. at 31.

108. See $i d$. and text accompanying note 52 . However, exceptions were made for situations in which the army had "operational need" to establish security; sealings, as opposed to demolitions, can also be conducted summarily in some "urgent cases." Welchman, Thousand Homes at 67-68.

109. According to the U.S. Department of State, the High Court has never overturned a deportation order. Country Reports at 116 (cited in note 67). This is at least technically inaccurate. In the one case in which an order was overturned, that of the summary deportations in 1980 of Hebron mayor Fahd Qawasmeh, Hebron religious leader Imam Rashid al- 
High Court rejected a petition filed in 1988 that would have required the military government to establish a court of appeals, the justices nonetheless strongly recommended that this action be taken. No doubt this pronouncement stimulated the military government's formation of the court of appeals the following year.

It is understandable that some would view this record of sympathy for procedural claims coupled with near deafness to substantive ones with cynicism. Of what comfort are procedural guarantees if substantive outcomes remain the same? The fact is, however, that the procedural rights in themselves have afforded a kind of limited relief in some cases and have led to substantively better results for Palestinian litigants, even if not dramatically better. In the case of home demolitions, for example, the mere delay in execution of a demolition order now required to process an appeal gives the occupants time to store movable property and arrange for their own shelter. This is a far cry from cancellation of an order, no doubt, but it is also a less severe hardship than being cast from one's home in the middle of the night with 30 minutes or less to remove one's most valuable belongings-as demolitions had taken place previously. ${ }^{110}$

Moreover, in a perhaps small but significant minority of cases, either the severity of sanction has been reduced or the proposed action of the military government nullified outright through review procedures mandated by the High Court. Home demolition orders have been modified to sealings in a number of appeals and reversed in at least a few. ${ }^{111}$ While sealings impose no less suffering in the short term, they are, for the most part, reversible-a fact for which many will be grateful if the Oslo accords are eventually implemented. ${ }^{112}$

Tamimi, and Halhoul mayor Muhammad Melhem, the military government completely circumvented appeal procedures laid down in prior High Court rulings. Two of the three were allowed to return to the Occupied Territories, present their appeals, and then were again deported, this time permanently. The deportation of Tamimi, who was alleged to oppose the existence of Israel, was upheld under caselaw permitting the High Court to deny otherwise appropriate relief to enemies of the state. Cohen, 24 Colum. J. Transnat'l L. at 502.

110. Note, however, that in a number of instances documented by Gaza attorney Raji Sourani, the military government has simply bypassed the review procedures and demolished homes without notice, as of old. See Welchman, Thousand Homes at 67-68.

111. Id. at 71. Of 94 challenges to home demolitions to reach adjudication before the court by mid-1991, 91 were denied. Another 22 were settled prior to judgment. One was remanded for factual errors in the text of the written order. Another was reversed after a finding that the offender to be punished did not reside in the home to be demolished. In the last, the military government had sought to seal two rooms and the kitchen in a home inhabited by 23 persons; the High Court barred sealing of the kitchen only. Simon, 19 Yale J. Int'l L. at 53.

112. Since the accords, the Palestinian Center for the Study of Non-Violence has mounted a campaign to reopen previously sealed homes in parts of the Occupied Territories not under Palestinian jurisdiction, in defiance of Israeli authorities. Sarah Helm, "No Open Doors on Sealed Homes; Sarah Helm Reports from Ramallah on Israel's Policy of Punishing Palestinians by Denying Them Their Family Homes," The Independent, 23 June 1994, at 16. 
While the Court has largely concerned itself with ensuring limited procedural safeguards against military government actions, in a variety of cases the Court has responded favorably to substantive claims of Palestinian litigants, handing them several spectacular victories. For example, in 1979, the court barred the military government's attempted acquisition of the Palestinian-owned East Jerusalem electrical power plant, compelled the Minister of Interior to grant a newspaper license to a Palestinian publication he had previously denied, and overruled the denial of an individual's attempt to reenter the West Bank to be reunited with his family. ${ }^{113}$

While upholding the general policy of holding detainees from the Occupied Territories in Israel, the justices of the High Court, after touring the Ketsiot prison facility in the Negev desert, ordered the military government to abate some of the problems of which prisoners had complained. ${ }^{114}$ The court also held the Military Advocate General to have abused his discretion in failing to prosecute an Israeli colonel suspected of having ordered soldiers to intentionally break the bones of Palestinian detainees. ${ }^{115}$ Petitions filed by the Association of Civil Rights in Israel challenging denial of access to legal counsel for detainees undergoing interrogation also were granted with regularity. ${ }^{116}$

In several of these cases, the High Court has established legal principles whose import extends far beyond the particular circumstances giving rise to the litigation. This is most true of two cases decided in the late 1970s in which Palestinian landowners fought land expropriation orders by the military government. In the first of these, the Beit El-Toubas case, the High Court affirmed the applicability of the law of belligerent occupation to the West Bank (and by inference, the Gaza Strip).117 In the Elon Moreh case, the High Court actually reversed a military order for the seizure of Palestinian property in the vicinity of the West Bank city of Nablus, holding that the Hague Convention permitted only the temporary requisition of private land in occupied territory for reasons of military necessity. ${ }^{118}$

To be sure, these cases did little in the short term to thwart the Israeli military government's program of land acquisition in the Occupied Territories. They did, however, influence the legal mode by which Israeli control over Palestinian-held land was asserted. Following a study by legal experts,

113. These cases, Jerusalem District Electricity Co. v. Minister of Energy (1979), El Asad v. Minister of Interior (1979), and Samara v. Regional Commander of Judea $\&$ Samaria (1979), are discussed in Shamir, 24 Law \& Soc'y Rev. (cited in note 20).

114. In Ibrahim Sagidia v. Minister of Defense, HCJ 258/88, the petitioners had argued that transferral of prisoners out of the Occupied Territories to Israel violated international law. Posner, Examination of Detention 9 (cited in note 5). note 7).

115. In Sofan v. the Military Advocate General, described in Yahav, Israel 80-81 (cited in

116. Human Rights Watch at 107 (cired in note 14).

117. See supra note 62.

118. Unofficial Translation of Dweikat v. Government of Israel, HCJ 390/79. 
the military government increasingly resorted to the "redemption" of lands it claimed as state domain. This tack was facilitated by the unsettled state of title as to a majority of lands in the region. After a pause, then, Israeli land acquisition in the Occupied Territories resumed, as did the settlement of Israeli civilians on those acquired lands. ${ }^{119}$

The full import of the High Court decisions on land acquisition in the Occupied Territories may yet to be realized. It is of potentially great significance that the High Court has declared virtually all forms of Israeli land holding in the Occupied Territories to be essentially temporary. ${ }^{120}$ To reiterate: The legal basis for land acquired by the military government through requisition is military necessity. Should that necessity end, so would the legal rationale for retention of the property. Land administered by Israel as "state" land requires either that Israel be the sovereign or that it operate as custodian to the sovereign.

Both these contingencies might well be eliminated for many Israeli civilian settlements in the West Bank and Gaza Strip if the recently concluded peace agreement progresses as planned. The ultimate fate of these settlements will doubtless be determined by political negotiations rather than by the legal principles declared long ago by the High Court. Yet these principles themselves may constitute powerful negotiating tools for the Palestinians, as well as grounds for an Israeli government to defend a policy decision to roll back settlements. ${ }^{121}$

If so, the High Court decisions that admittedly did little initially to halt the march of Israeli land acquisition in the Occupied Territories will prove in the end to be the loose thread that unravels the skein of Israeli settlements in the West Bank and Gaza Strip. This would be a major step toward restoring control of land and water resources in those regions to Palestinians, vital elements in their struggle to achieve self-determination in their homeland.

Palestinian petitioners to the High Court have been not only individuals-homeowners facing demolition orders, deportees, administrative detainees-but also Palestinian entities-schools, universities, charitable associations, unions, and the like-that form the potential institutional core of a future Palestinian state. Though one must search the High Court record carefully for examples of Palestinian victories, they can be found. These victories may be viewed as paltry, but they must not be scoffed at, in

119. These developments are examined in detail in I. Lustick, "Israel and the West Bank after Elon Moreh: The Mechanics of De Facto Annexation," 35 Middle East J. 557 (1981).

120. This would not be so of the relatively small proportion of land purchased in the Occupied Territories by Israeli individuals and organizations. R. Shehadeh, Occupier's Law 39 (2d ed. 1988).

121. As noted above, settlements are among the matters specifically excepted from the jurisdiction of the Palestinian interim self-governing authority contemplated by the Declaration of Principles signed 13 Sept. 1993. See supra note 21. 
view of the suffering they have spared even a few real litigants and, perhaps, even more, for their still unrealized political implications.

\section{BEYOND LITIGATION}

There are at least two major categories of activities in which lawyers defending Palestinian clients from the Occupied Territories regularly engage outside the courtroom as alternatives to litigation but which still emanate proximately from their professional roles. The first is direct intervention with military government administrators, and the second is resort to the "court of public opinion." As both depend on litigation for their efficacy in one sense or another, it is appropriate to include the benefits so gained in our inquiry. ${ }^{122}$ Let us examine each in turn.

The High Court's influence over affairs in the Occupied Territories cannot be measured simply by the win-loss record of Palestinian litigants in cases reaching adjudication. Rather, the threat of litigation in the High Court has a certain deterrent effect on the military government. ${ }^{123}$ This threat almost surely establishes the viability of direct intervention with administrative authorities-informal pleas for relief directed to the military government itself. This is a common first line of attack for lawyers representing affected parties and occasionally yields positive results. ${ }^{124}$

Some interventions might well have been productive even without the shadow cast by the High Court in the Occupied Territories-when, for example, the military government's proposed actions were the result of mistake or were otherwise misguided and unnecessary. However, the threat of legal challenge has forced the military government into a different accounting of its interests in completing challenged measures. Litigation has inevi-

122. One index of the necessity of litigation to the viability of direct interventions and appeals to public opinion is the virtually complete absence from these fields of activity of the striking lawyers.

123. See, e.g., Yahav, Israel (cited in note 7); Cohen, 24 Colum. J. Transnat'l L. (cited in note 63); and Negbi, "On Occupation, Intifada, and Constitutional Crisis in Israel," 52 Jerusalem Q. 18 (1989). Yahav cites several examples in which the military government adopted measures favorable to residents of the Occupied Territories in anticipation of High Court litigation. The deterrent influence of the High Court is also acknowledged by Palestinian lawyers. See J. Kuttab, "Avenues Open for Defence of Human Rights in the Israeli Occupied Territories," in E. Playfair, International Law in the Administration of Occupied Territories (1992) ("Kuttab, 'Avenues").

124. The intervention may take the form of letter writing or personal meetings with officials from the military government department responsible for the action which gives rise to the complaint, or with members of the office of the Legal Advisor to the military government, or, on occasion, with officeholders in government ministries in Israel.

The rarity of striking lawyers' engagement in this type of lobbying for client's interests may reflect the latters' unwillingness to entrust claims to attorneys who are unwilling or unable to pursue every possible path to relief, including litigation. Such work would also violate the spirit, if not the letter, of the strike-one rationale for which, it will be recalled, was to protest the overall illegality of Israeli occupation. See supra note 32. 
tably involved at least tangible costs-delay and manpower at a minimum. Other costs might be uncertainty, fear of embarassment at exposure of morally questionable practices, or challenges to its image of complete invincibility before a subject population controlled predominantly, if not exclusively, through force and intimidation. ${ }^{125}$

Advocates for Palestinian clients in the Occupied Territories have developed increasing sophistication in using appeals to public opinion to constrain the military government's powers, sometimes producing palpable gains in individual cases. ${ }^{126}$ More important, such appeals to both domestic Israeli and international public opinion have helped curb some of the worst excesses of Israeli military government, chief among them, the practice of torture in interrogations of Palestinian detainees. ${ }^{127}$

Lawyers have been key players in the campaign to publicize the practice of torture and ill treatment in Israeli detention centers by taking a role in local human rights monitoring and documentation organizations. ${ }^{128}$ Their efficacy in the campaign to end torture was a direct outgrowth of their experience with clients and litigation in the military courts.

The campaign's goal has obviously not yet been attained. But there has been a demonstrable shift in GSS interrogation techniques away from severe beatings and inflictions of permanent bodily injuries, and toward low visibility physical and psychological abuse. ${ }^{129}$ There is no doubt that the shift in interrogation techniques is a direct outgrowth of the Landau Com-

125. All three of these factors were probably at work in the military government's occasional abandonment of plans to demolish homes in the period before that policy gained High Court approval. See supra note 112 and accompanying text, and Simon, 19 Yale J. Int'l L. (cited in note 52), who comments perceptively that exhibition of might is essential to the maintenance of the authority of a belligerent occupant within a hostile population, and argues that this, rather than deterrence, has been the primary force driving the Israeli policy of home demolitions.

126. Jonathan Kuttab, "Avenues" at 501 (cited in note 123), reports, e.g., that interventions of Palestinian human rights organization al-Haq on behalf of aggrieved Palestinians that were copied to international organizations received more prompt and positive results than other cases. Appeals to public media or to politicians, as opposed to administrators, however, bear the risk of foreclosing High Court litigation. In Mohamed Sa'id Burkan v. Minister of Finance, the High Court ruled "a petitioner seeking relief from this court is obliged to keep silent outside the courtroom, lest his recourse to the media be construed as an expression of no confidence in the court," and further suggested that the petitioner's attorney be investigated for a violation of professional ethics due to his contacts with news media over the case. Quored in Kenneth Kahn, "Israel Denies Muslim's Right to Live in Jerusalem's 'Jewish Quarter,' "Washington Report on Middle East Affairs, July/Aug. 1993, at 90.

127. See supra notes $76-84$ and accompanying text.

128. Among the local organizations in which lawyers have played seminal or supportive roles are al-Haq in the West Bank and the House of Right and Law and Palestinian Lawyers for Human Rights in Gaza. Virtually all the reports on torture in Israel by international groups have relied extensively on local lawyers for documentation of cases of abuse and for perspective on the handling of such cases in the military court system. For example, Human Rights Watch (cited in note 14) supplemented its own sample of 36 face-to-face interviews of persons alleging abuse during interrogations with five further interviews of then-incarcerated interrogatees conducted by their lawyers for its recent report.

129. See supra notes 83 and 84 and accompanying text. 
mission and an indirect product of the campaign against torture that both preceded and continued after the commission's report. Thus it is plausible to credit Palestinian and Israeli lawyers with substantial responsibility in compelling the shift.

It may seem bizarre to applaud lawyers for what arguably constitutes complicity in the rationalization and sanitation of torture. Surely the new techniques, leaving yet subtle or no physical traces, are even harder to document and to establish in the courtroom. Still, the new trend in interrogation represents a net subtraction from the repertory of techniques formerly enjoyed by GSS and IDF interrogators. Most of the trickery and abuses composing the current interrogation technology were practiced well before 1991.130 One might argue, therefore, that interrogators now have fewer weapons to employ than before. As with house sealings, reversible losses, ones from which recovery is at least a potentiality, are preferable to irreversible ones. Current practices, on the whole, seem less likely to result in permanent physical injuries than the former beatings and other abuses. ${ }^{131}$

The question remains whether the psychological scars from a more incremental regime of abuse are worse than a shorter, but more physically brutal one. I cannot answer that question, but the other factors mentioned above weigh in favor of the new trend. In light of the military courts' prior record of uniform denials of challenges to the voluntariness of statements, the lesser detectibility of the recent techniques would seem, as a practical matter, to make not a whit of difference, and therefore does not alter the balance one way or the other. ${ }^{132}$ Thus, I maintain, the lawyers' efforts to end maltreatment of Palestinian detainees, though unrealized, have nonetheless exercised a mild ameliorating influence.

\section{LEGITIMACY COSTS}

We have reviewed the gains-modest, to be sure, but palpable nonetheless-that Israeli and Palestinian lawyers have been able to achieve on behalf of residents of the Occupied Territories. Now we must ask: At what cost? Has - and does-the participation of Palestinian and Israeli lawyers in a legal system they often denounce, defeat their very commitment to ending

130. For example, I gathered allegations of similar practices in the mid-1980s; see Bisharat, Palestinian Lawyers $139-40$ (cited in note 3 ). Nor was I given to understand that the practices were new at the time.

131. Though I reemphasize: findings indicate that beatings, sometimes severe, continue to occur with some regularity. See Human Rights Watch at 65 (cited in note 14). The same report also records the emergence of one Palestinian from recent interrogation in an as-yetirreversible catatonic state. Needless to say, the exact causes of the detainee's condition remain unknown.

132. As the recent Human Rights Watch report attests, the shift has not deflected international detection and criticism of Israeli interrogation practices. 
military occupation? Has their advocacy ultimately legitimated the occupation or contributed to its prolongation?

This question cannot be posed fruitfully without discussion of the various "audiences" within which the occupation may be legitimated. Here I briefly discuss only three: the Palestinian community under occupation; the international community; and the Jewish Israeli public. ${ }^{133}$

The suggestion that the legal edifice which Israel has taken some pains to erect in the Occupied Territories has legitimated in the eyes of the Palestinians the expropriation of Palestinian lands, or the imprisonment of thousands of Palestinians, or the military government as a whole is ludicrous. The Intifada, which erupted in late 1987 as a spontaneous outburst of hostility against the occupation, is perhaps the most graphic evidence that Israeli authorities have never gained legitimacy among Palestinians in the Occupied Territories.

Of course, Israel has never expected, nor sought, the political allegiance of the Palestinians of the Occupied Territories as their sovereign. Indeed, doing so would have invited a political disaster-that of having to grant citizenship rights to more than 1.5 million Palestinians and accept the impact of their enfranchisement on the Israeli polity-or deny them such rights and live with rather more patent gradations of citizenship. ${ }^{134}$ Rather, the primary goal of military government policies has been minimal compliance with Israeli rule. ${ }^{135}$

The real question, then, is whether either the military court system in the Occupied Territories or the High Court's oversight over military government contributed to some lesser form of legitimacy among Palestinians, or legitimated among them something other than Israeli rule of the regions per se. One possibility is that the military courts and High Court gained for themselves a form of institutional legitimacy, that while failing to reconcile

133. Cf. Shamir, 24 Law \& Soc'y Rev. at 783 (cited in note 20). In fact, only the first of these three audiences, the Palestinian community under occupation, even approaches homogeneity, at least in its stance vis-à-vis the occupation. One might refer more accurately to numerous subdivisions within the other two. E.g., meaningful distinctions might be drawn between the U.S. and European governments, between the U.S. government and the American public, and various of its constituent elements, such as Jews supportive of Israel, etc. Not all these subdivisions view Israeli policies in the Occupied Territories identically. The Israeli polity is also highly complex, and evolving, and its various political, social class, and ethnic subelements respond to occupation policies differently as well. I will at least point to some of these subaudiences infra.

134. See Lisa Hajjar, "Zionist Politics and the Law: The Meaning of the Green Line," 2 Arab Stud. J. 44-50 (1994). As to classes of citizenship in Israel, see also David Kretzmer, The Legal Status of the Arabs in Israel (1990).

135. In the early years of occupation, as one administrator wrote, there was hope: "[T]o change the image of Israel in the Arabs' eyes, and we have accomplished quite a lot in 'this direction during the last four years. The inhabitants of the Territories now know what Israel is, as compared to what official Arab propaganda says. Israel wants to convince these residents that they have a very keen interest of their own in the continuation of coexistence." Gazit, "Policy in the Administered Territories," 1 Israel Y.B. Hum. Rts. 278, 281 (1971). 
Palestinians to Israeli occupation, might indirectly have played a role in defusing Palestinian opposition to it.

Yet no amount of procedural nicety would have seemed capable of altering the Palestinians' view of the military legal system, judged almost solely by its substantive product, as simply another weapon in the occupation authorities' arsenal to suppress Palestinian national aspirations. This was the predominant perspective on the military courts of nearly all Palestinians I spoke with during my 14 months of research in the West Bank in the mid-1980s. ${ }^{136}$ The physical decrepitude of the military court quarters was for many a symbol of the Israeli government's minimal investment in services and institutions vital to Palestinians. ${ }^{137}$

West Bank and Gaza lawyers, aware of the considerably higher standards of justice in the adjacent Israeli civil courts, evinced a bewildered hurt that a society capable of organizing and maintaining an effective legal system for itself would offer so little of the same to their community. It was not as if the courts could not have established some legitimacy among the lawyers-they, on the contrary, seemed to have begun with a nearly naive trust in the bona fides of Israeli legal institutions. The military tribunals simply had not capitalized on that initial trust, rather, had spurned it through their coldness to Palestinian pleas for even mercy, let alone justice.

There is, perhaps, one significant sense in which the military courtsor more precisely, military judges - gained some respect among Palestinian lawyers, and in a way that might have had a palliating effect. Before the Intifada, at least, many West Bank Palestinian lawyers assessed the military court system as "good judges, bad law,"138 compared with Palestinian judges in the civil court systems. Whereas the native judges were viewed as venal, imperious, irascible, poorly educated, and not interested in legal argument, ${ }^{139}$ Israeli judges were sometimes described as honest, patient, respect-

136. See supra note 3. On the other hand, Lisa Hajjar, conducting doctoral research in the Occupied Territories on the military courts in the early 1990s, suggests that some Palestinian defendants see the courts as relatively neutral fields of contest and blame their attorneys, rather than the military legal system as such, for the predictably unsatisfactory dispositions of their cases. Hajjar, personal comm., 21 Oct. 1994.

137. See supra note 44 and accompanying text.

138. The Intifada was a watershed event in the Occupied Territories in many respects, among them, in causing a marked increase in tensions between lawyers and judges in the military courts. One need not search far for the causes: the heightened tensions within the region as a whole were reflected immediately in the tremendous increase in arrests and crush of cases in the military courts. This, in turn, led to Israeli efforts to expedite the processing of cases, typically in ways that lawyers saw as jeopardizing their clients' already minimal rights. As previously mentioned, lawyers in both Gaza and the West Bank responded by declaring strikes against the courts, one, in 1989, persisting for two months. See supra note 55. On the impact of the Intifada on the military court system, see Yahav, Israel 92-99 (cited in note 7).

139. Only the very few practicing West Bank lawyers who harked back to the period of the British Mandate had memory of a more competent local judiciary. Those who had practiced then held fairly condescending views of the judiciary during the Jordanian era. Bisharat, Palestinian Lawyers 24-29 (cited in note 3). 
ful of attorneys, and willing to hear out defense lawyers, and to engage in the to-and-fro of lawyerly discourse. ${ }^{140}$

Having such judges was arguably a boon to the Palestinian community, though a quite intangible and indirect one. ${ }^{141}$ Yet the traces of another process are manifested in the characterization Palestinian lawyers offered of the military judges: what one might term the depersonalization of the exercise of repressive power. Judges were not responsible for the injustices suffered by Palestinian clients-the laws were. For the first 20 years of occupation, this effect, perhaps even more valuable to Israeli judges than to Palestinian lawyers operated like a lubricant to the military legal system, ensuring the continued dispensation of punishment of Palestinians while minimizing friction between its necessary "moving parts"-the functionaries who staffed and operated the courts.

This brings us to another troubling possibility. Above I suggested that the rational course of action for most defendants in the military courts was not to contest their guilt through trial but to plea bargain in order to minimize sentence. The unspoken premise there was that this course maximized the individual client's self-interest. Did lawyers, in helping-perhaps on occasion, enjoining-defendants to pursue this rationality, preclude or dissuade the adoption of a more confrontational approach? And if so, was this done in part to spare lawyers the increased workload, stress, and dangers of more direct challenges to military authority? ${ }^{142}$ Were they, in a sense, engaged in inducing compliance to military rule at the level of the individual client? ${ }^{243}$

Without question, the military courts afforded lawyers and defendants little room to maneuver. On the other hand, had both defendants and lawyers been willing to make the sacrifice, there is little question that through nothing more than a collective determination to refuse to plea bargain, and instead to insist on trials in every case, Palestinians would have been able to impose substantially greater costs on the military government. If this strategy, in turn, had led to earlier, and more intense criticism of the occupation

140. Of course, as the Israeli military government had assumed power over judicial appointments in the West Bank since 1967, the impoverishment (as it was perceived by local lawyers) of the Palestinian judiciary was itself laid at the doorstep of the Israeli officer in charge of the civil court system. This impoverishment, incidentally, had a literal aspectjudicial salaries were, for many years, so low as to invite corruption, the singlemost serious flaw noted in the local courts. See my Palestinian Lawyers 125-44, and Kuttab \& Shehadeh, West Bank (cited in note 20).

141. Cf. Ellmann, Time of Trouble (cited in note 38), who argues that the preservation of the values of judicial independence and the rule of law by South African courts conferred benefits to the society that will be realized in the post-apartheid period.

142. An analogy to public defenders in the United States springs to mind here. See Arthur Blumberg, "The Practice of Law as a Confidence Game: Organizational Cooptation of a Profession," 1 Law \& Soc'y Rev. 15 (1967).

143. I am indebted to James Ron for pointing out the potential individualizing influence of lawyers' work in this context. 
within Israel and elsewhere, it may have inured to the benefit of the Palestinian community under occupation at large. ${ }^{144}$

We do know that this tactic was practiced only fleetingly, and then during the Intifada only in some locales. Although I have no evidence that lawyers actively discouraged such an approach, it is further my strong impression that they never touted it. In fact, it appears that there was never any coordination between lawyers representing. Palestinians in the military courts and political cadres within the Palestinian national movement. ${ }^{145}$ It would seem natural, however, that in the absence of such a general political strategy toward the military courts, lawyers would address the problems of their clients as they encountered them-as individual ones.

We lack the empirical experience to evaluate this largely unexploited tactic of noncooperation. Of course, its adoption might only have resulted in swelling Israeli prison populations and depriving the political movement outside the prisons of its most experienced members. We cannot know what resources the military government would have been willing to commit to repel such an institutional assault.

The Israeli High Court, of course, is a distinct institution, with a much less overt role in the suppression of Palestinian nationalism than the military courts and with a more nuanced record for treatment of Palestinian claims. Indeed, there may have been a brief period in the few years following its string of rulings favorable to petitioners from the Occupied Territories in 1979 when it won itself-though not the military government whose measures it reversed-a quantum of legitimacy among Palestinians. ${ }^{146}$

Yet, like the military courts, the High Court's otherwise largely unfulfilled promise of relief from arbitrary military government actions arguably has engendered greater cynicism among Palestinians toward Israeli rule than might have been true had military government policies been pursued by unmediated force. One empirical study of Palestinian petitioners to the High Court reported: "The overwhelming finding of this study is that plaintiffs, as well as their lawyers, express total disbelief in the availability and

144. In my four-year practice as a public defender in San Francisco, CA, the fantasy of bringing the hall of justice to a grinding halt by trying every case was bandied about often among defense atorneys (usually the younger among us) as a means to discipline either judges or prosecutors who were behaving "unreasonably." That intoxicating prospect, somehow, never got translated into action.

145. As to this I may be simply naive. The problem, of course, is that avowal of such coordination could well lead to charges against lawyers, even in the present. See supra note 5. The time may not be distant when this question can be better answered.

146. See supra note 113 and accompanying text; the reversal of the military requisitioning of land for Israeli settlement in the Elon Moreh case was also handed down in 1979. I am not aware of any single factor that explains the series of Palestinian victories in the High Court. 
scope of favorable court decisions and are skeptical about the availability and scope of negotiated settlements."147

It was precisely because Israel championed the High Court and the extension of its jurisdiction to the Occupied Territories, as an emblem of its commitment to democracy and the rule of law that Palestinian lawyers and others found its perceived deviations from that ideal most offensive. Moreover, the ease and impunity with which the military government could simply amend or replace legislation meant that any legal gains achieved by Palestinians could be reversed at the flick of the area commander's pen. ${ }^{148}$ This left lawyers with the sense of participating in a legal shell game in which they could never match their opponent's sleight-of-hand.

Why did Palestinians persist, even in increasing numbers, as the occupation wore on, in resorting to High Court litigation? Did their actions not bespeak their trust in that institution? Shamir suggests that one explanation of Palestinians' doggedness in the face of almost certain legal defeat was not a tangible benefit as such, but simply the desire "to be heard."149 Doubtless this has been a motivation for some, perhaps many, Palestinian petitioners. There is more at work here, I think: a stubborn Palestinian pride and unwillingness to surrender to perceived injustice; a fierce determination to exact the maximum toll from one's oppressor, in whatever form possible and no matter the cost to oneself; and a small residue of hope in a positive outcome, though one sufficient to spur further investment of resources in light of the often precious commodities at stake. ${ }^{150}$ There are elements in all but the last of these factors of continued, quiet resistance to Israeli rulethe steadfastness that Palestinians have come to call sumud-rather than acceptance of the legitimacy of its courts. ${ }^{151}$ Also, while some Palestinians

147. Ronen Shamir, "Litigation as Consummatory Action: The Instrumental Paradigm Reconsidered," in A. Sarat \& S. Silbey, eds., 2 Studies in Law, Politics, and Society 53 (1991) ("Shamir, 'Litigation' "). This is corroborated by Kuttab, "Avenues" (cited in note 123).

148. In theory, the High Court treats the military government's legislation in the Occupied Territories as it does any of its other administrative acts-as subject to judicial review under the international laws of belligerent occupation and Israeli administrative law. See Nathan, "Power of Supervision" (cited in note 57). In practice, however, no legislative act by the area commanders of the West Bank or Gaza Strip has ever been overtumed by the High Court. Raja Shehadeh, "The Legislative Stages of Israeli Military Occupation," in E. Playfair, ed., International Law and the Administration of Occupied Territories (1992).

149. Shamir, "Litigation."

150. It is suggestive that home demolitions, though far less frequent a sanction than, say, administrative detentions, have been the most often challenged measures in the High Court for a number of years. See Simon, 19 Yale J. Int'l $L$. (cited in note 52). In 1986, 22.8\% of the petitions brought from the Occupied Territories involved home demolitions or sealings, followed by those against restrictions on personal movement (17.5\%). Avishai Ehrlich, "'Bagatzim'-Petitions to the High Court-a Statistical Portrait," Istaeli Democracy, May 1987.

151. While clearly the ethic of "not going down without a fight" is shared across many societies, Palestinian society (and Arab society generally) is one in which the ethos of honor is pronounced and in which willingness to undergo privation to preserve honor is especially venerated. On honor in Palestinian society see Palestinian Lawyers 37-39 (cited in note 3). A 
opted to petition the High Court, the overwhelming majority of those suffering as a result of military government actions did not.

Still, Shamir's perception of the value to Palestinians of being granted a voice within one of Israel's most important national institutions must be taken seriously, and its implications further assessed. It suggests yet another way in which the High Court may have served to mitigate Palestinians' resistance to military government measures. This may occur in either or both of two ways.

First, to the extent that Shamir's claim is correct, High Court litigation offered Palestinians a form of symbolic compensation for their actual, tangible losses. It thereby skirted a more volatile circumstance in which Palestinians suffering at the hands of the military government would be left absolutely empty-handed and without peaceful outlet for expressing their frustrations. ${ }^{152}$ Interestingly, this appears to have been one of the conscious rationales for the extension of High Court jurisdiction to the Occupied Territories and for the Israeli executive branch not challenging the questionable legal theory on which that jurisdiction has rested. ${ }^{153}$

Second, High Court litigation introduces a sometimes substantial time lag between Palestinians' first awareness of impending military government acts and their execution, during which moral outrage over the acts may be tempered by the maintenance of even remote hopes for legal relief. This

specifically nationalist overlay was given to this sentiment in the Occupied Territories, where sumud, or tenaciousness in remaining on the land against perceived Israeli pressures to leave, became the sacred duty of all Palestinians. Cf. James Scott, Weapons of the Weak: Everyday Forms of Peasant Resistance (1985).

152. Perhaps the willingness of military court judges to hear out Palestinian lawyers should be reevaluated in this light as well. Thomas Friedman records an anecdote involving Palestinian lawyer Raja Shehadeh, who, along with a number of other advocates, had gone to Jneid prison in the West Bank to challenge the administrative detention of their clients:

"The judge sat down," recalled Shehadah [sic], "leaned back in his chair, and announced, 'Who would like to speak?'

"I said, 'What should I speak about? Where are the charges? Where is the evidence?' "He said, 'It is a free place-speak about whatever you want.'

"So first one lawyer stood up, then another, and another, and they each spoke about their clients," Shehadah recalled. "There was no reaction from the judge, no court reporter taking anything down. We were just little children he wanted to please by letting us speak to our heart's content. ... . So we all spoke to our heart's content, and then the judge asked us to please leave the room. After a while, we were called back. All the prisoners were there ... so he [the judge] ordered the fifteen prisoners to stand and then he announced, 'I confirm the administrative detention order for all of you."

Thomas Friedman, From Beirut to Jerusalem 352-54 (1989) ("Friedman, Beirut").

153. See supra note 57 and accompanying text. Meir Shamgar, current President of the High Court, was, in his capacity at the time as Attorney General, the official most responsible for the decision to authorize High Court jurisdiction in the Occupied Territories. Among concerns for upholding the rule of law and protecting human rights, Shamgar saw the Court as "the best outlet for the bitterness of the occupied territories' inhabitants." Cohen, 24 Colum. J. Transnat'l L. at 473 (cited in note 63). See also Negbi, 27 Jerusalem Q. 33 (cited in note 57). One is tempted to say this symbolic offering was cheap; recall, however, that it involved some fairly high risks and imposed some real limitations on the actions of the military government in the West Bank and Gaza Strip. 
delay offers Palestinians a period of reconciliation to their coming deprivation, and thus can cushion the military government from more extreme resistance.

Finally, we must to consider the argument-propounded passionately by West Bank lawyers who have upheld the boycott of the courts-that, as members of a vanguard profession in society, lawyers had a special responsibility to the larger Palestinian community not to capitulate to Israeli occupation. Work in the courts of the occupier, such lawyers maintained, could only signal such capitulation. ${ }^{154}$

As this hints, the original orientation of the strike truly was to an Arab audience-first Palestinian and, perhaps secondarily, Jordanian. In fact, neither demands nor conditions for the strike's end were ever issued to Israeli authorities. There was no attempt to communicate with the Israelis at all, beyond the testimonial of the refusal to practice itself-and that, I think, was almost purely incidental.

The argument that lawyers' resumption of "business as usual" would signal a damaging capitulation may have had force in the earliest days of occupation, when there was great uncertainty about the possible duration of Israeli rule. Beyond that period, however, legal advocacy in Israeli courts was a bow to the undeniable reality, already apparent to all other sectors of Palestinian society, that military government was there to stay for the forseeable future.

In sum, I maintain, the military court system and the Israeli High Court were neither deployed for, nor succeeded in, wooing of Palestinian assent to Israeli occupation. However, in several subtle and indirect ways, Israeli courts may have played a role in inducing Palestinian compliance with military administration. ${ }^{155}$

Israel has worked hard to guard its image abroad as a democratic nation that respects the rule of law and has been highly sensitive to international criticism of its policies in the Occupied Territories. For example, in the late 1970s, the Israeli government established human rights divisions within the Ministry of Justice and the Foreign Ministry to respond to foreign inquiries into human rights issues, primarily in the Occupied Territories. ${ }^{156}$ Israeli lawyers involved in the military administration issued monographs in Eng-

154. There were, no doubt, pragmatic calculations underlying the strike as well. At the time the strike was declared, no one in the Occupied Territories foresaw anything but a rapid return to Jordanian administration. Lawyers must have had some qualms about how appearances in Israeli courts would be received by the strongly Arab nationalist Jordanian Lawyers' Union (of which they were members) and by the Jordanian government. Indeed, the JLU and the regional Union of Arab Lawyers later expelled West Bank working lawyers from their ranks, although at the urging of the still-striking contingent. Palestinian Lawyers 145-49.

155. Zureik et al., 25 Int'l J. Middle East Stud. (cited in note 59), conclude similarly for Palestinians and the legal system in Israel itself.

156. Weiner, "Terrorism: Israel's Legal Responses," 14 Syracuse J. Int'l L. \& Commerce 403-33 (1987). 
lish in defense of Israel's legal regime. ${ }^{157}$ There are, I suspect, two fundamental reasons for Israel's deep concern to maintain its preferred image within the international community. The more prosaic of these reasons, though not necessarily the more powerful, is Israel's dependence on foreign economic and military aid, particularly from the United States. Direct government-to-government transfers of funds from the U.S. to Israel from 1948 to 1991 totaled $\$ 53.5$ billion, over $\$ 40$ billion of which was given after 1979.158 But the flow of U.S. aid has occasionally been disrupted, notably during the Bush presidency, when loan guarantees to Israel were suspended due to American dissatisfaction over continued settlement of Israeli civilians in the Occupied Territories. ${ }^{159}$ Thus Israel has had reason to believe that breaches in its international image as a law-abiding state can bear heavy costs. ${ }^{160}$

The second reason is that Israel's self-image is in part constructed from the reflections it sees of itself in the mirror of international opinion. Being counted as a member of the fellowship of democratic, law-abiding nations of the world is an important ideological resource and cause for pride in Israel, especially among its historically Western-oriented governing elites.

Be that as it may, it is evident that Israeli efforts to protect its image have not legitimated Israeli occupation of the West Bank and Gaza Strip in the eyes of the international community, at least in providing normative justification for the permanence or indefinite continuation of that occupation. The international consensus has never strayed from its position, re-

157. See Singer, Rule of Law (cited in note 16). Yoel Singer was a lawyer working for the military government. As the preface by former Israeli High Court Justice Haim Cohen indicates, Singer's work is a direct response to an earlier critical volume by Palestinian lawyers Raja Shehadeh and Jonathan Kuttab. Military Government in the Territories Administered by Israel 1967-1980: The Legal Aspects, was edited by current President of the Israeli Supreme Court, Meir Shamgar. In his former capacity as the Military Advocate General, Shamgar was the principal architect of the military legal system in the Occupied Territories. A third work, Israel, the "Intifada" and the Rule of Law, was written mostly in 1990, a period during which Israel's image abroad was suffering considerably due to its attempts to suppress the Intifada. The editor-in-chief, David Yahav, was a colonel in the IDF and a Deputy Military Advocate General.

158. Ball \& Ball, The Passionate Attachment 282 (1992). Levels of aid in the years since 1991 have not diminished significantly: $7.8 \%$ of Israeli government annual expenditures ( $\$ 38.6$ billion) is covered by U.S. economic and military aid ( $\$ 3$ billion); the U.S. is also the largest holder of the Israeli government's $\$ 17$ billion foreign debt. See CIA World Factbook (1993).

159. See John Goshko \& Helen Dewar, "Israeli Loan Guarantees Appear Doomed; Bush Refuses to Drop Linkage to Freeze on Jewish Settlements," Washington Post, 18 March 1992, at A1. The Clinton administration announced in October 1993 that it would cut aid to Israel earmarked to resettle immigrants from the Soviet Union by the amount spent by Israel on settlement activity in the Occupied Territories. David Horowitz, "Clinton Aid Cut Shocks Israelis," Fin. Times, 7 Oct. 1993.

160. This is true not only in Israel's relations with the United States but also in its dealings with trading partners and others. E.g., in the early phase of the Intifada, the European Parliament voted to freeze scientific cooperation between EEC members and Israel as a result of the closure of West Bank universities. David Makovsky, "European Parliament Votes to Punish Israel," Jerusalem Post, 21 Jan. 1990. 
flected in U.N. Security Council Resolution 242, that Israel should withdraw from the territories it occupied in the 1967 war, in return for guarantees of the right to live in peace within secure and recognized boundaries. ${ }^{163}$

On the other hand, the very fact that Israel has deployed the legal institutions it has in the West Bank and Gaza Strip transformed the very terms of discourse on its rule there. As Snyder remarks of the Argentinian junta's maintenance of the court system during states of siege:

From the junta's perspective, it matters not whether the government "wins" or "loses" one case or another. It will always find a way to disregard or neutralize the effects of a really threatening decision. . . What is important is that it appears to be an actual player in the game of legal rhetoric, a partner with court, petitioner, and legal analysis in the search for legality and justification. ${ }^{162}$

In a similar vein, Israel's offer of the right to petition its High Court to residents of the Occupied Territories has been extolled by its sympathizers as an enlightened measure, unprecedented in the history of military occupations. ${ }^{163}$ Meanwhile, the fact that the High Court has never seriously constrained the military government's power has been recognizable only upon considerably more attentive study.

In countries like the United States, the resulting image of a "benign occupation" in the West Bank and Gaza Strip may have helped to insulate Israel from the kind of public debate that has often surrounded U.S. provision of military and economic aid to outright authoritarian regimes. ${ }^{164}$ If that is so, even while the occupation was never legitimated as a permanent state of affairs, the aid which made it possible was permitted to flow with little or no interruption and with lower political cost to U.S. policymaking elites than they might otherwise have incurred.

161. U.N. Security Council Resolution 242 of November 1967, contained in H. Cattan, Palestine and International Law (1973). The resolution was further reaffirmed in Oct. 1973, April 1975, May 1975, July 1975, Oct. 1975, May 1976, Nov. 1976, Nov. 1988, and Oct. 1990 (all calling, by unanimous or nearly unanimous decision, for the implementation of Resolution 242 (1967) in all of its parts); not to mention an equally lengthy chain of General Assembly resolutions.

162. F. Snyder, "State of Siege and the Rule of Law in Argentina: The Politics and Rhetoric of Vindication," 15 Lawyer of the Americas 503, 519 (1984).

163. See, e.g., Shamgar, Military Government (cited in note 8); Yahav, Israel (cited in note 7); Israeli \& Ehrenfeld, "Between the Peak and the Pit: Human Rights in Israel," 13 Syracuse J. Int'l L. \& Commerce 403-33 (1987); Weiner, 14 Syracuse J. Int'l L. \& Commerce.

164. American public opinion has been fairly stable in its support for Israel since its creation in 1948. The first significant deviation from this pattern occurred with Israel's invasion of Lebanon, in 1982, which cast Israel for the first time among Americans as a clear aggressor. There was similarly a sharp drop in sympathy for Israel during the first years of the Intifada, when pluralities of Americans believed that Israel's response to the uprising was overly harsh. See Benjamin Page \& Robert Shapiro, The Rational Public 251-61 (1992). 
This, however, is a consequence of Israel's generally legalistic style of governance in the Occupied Territories and not of the legal advocacy of politically committed lawyers working to protect Palestinian interests. Its benefits would likely have accrued to Israel whether or not these lawyers, toiling in relative obscurity, had represented Palestinians in the military courts or pressed their claims in the High Court.

Of course, there are some refinements to the military legal system-for example, the procedural rights of prospective deportees or the establishment of the military court of appeals, that, as we have seen, are more or less directly attributable to the efforts of lawyers working for Palestinians in the Israeli High Court. It is also true that these refinements have on occasion been lauded by groups watchful of Israel's policies in the Occupied Territories. ${ }^{165}$ But it seems improbable that those few legal experts whose scrutiny is sufficiently exacting to even notice such reforms would misconstrue the failure of the reforms to rectify the major flaws in the military legal system. ${ }^{166}$ This increment of legitimation, though real, therefore seems of minimal weight.

A condition essential to the ability of Israeli courts to legitimate military occupation of the West Bank and Gaza Strip among Jewish Israelisand to be clear: it is in relation to this audience, and to specific subgroups within it, that I believe the courts to have played a significant role in legitimating occupation -is the near total segregation of Jewish Israelis from Palestinians in the Occupied Territories. Most Jewish Israelis live in population centers geographically removed from the Occupied Territories and, given the climate of hostility that has prevailed since 1967, venture there seldom or not at all. Those who live near or even within the West Bank or Gaza Strip are often whisked to work along highways deliberately designed to bypass Palestinian population centers. Language barriers further inhibit communications and learning across the "Green Line," a vestige of the old border between Israel and the regions it occupies. As a result, most Israelis are little in touch with the realities of daily life for Palestinians in the Occupied Territories. ${ }^{167}$

165. E.g., a mission of the International Commission of Jurists to the Occupied Territories in summer 1989 noted with approval the establishment of the appeals court. Jordan Paust, Gerhard Von Glahn, \& Gunter Woratsch, "Report of the ICJ Mission of Inquiry into the Israeli Military Court System in the Occupied West Bank and Gaza," 14 Hastings Int'l $\mathbb{E}$ Comp. L. Rev. 1 (Fall 1990).

166. The ICJ mission mentioned in note 166 visited the Occupied Territories just months after the establishment of the appeals court and thus was limited in its capacity to evaluate the court's impact. The mission, overall, was highly critical of Israel's administration of justice in the West Bank and Gaza Strip.

167. This is not meant to be pejorative; I am certain most Palestinians of the Occupied Territories are equally ignorant of everyday life among Jewish Israelis. The latter fact is simply not relevant here.

To cite an example: It was a revelation for many Israelis to discover that IDF soldiers had orders never to shoot at Jews in the Occupied Territories, a fact which came to light during 
Yet Israelis are anything but indifferent about government policies in the Occupied Territories. On the contrary, those policies have been a focus of considerable public attention and debate within Israel since 1967. The High Court-a body seen as "above politics" in an otherwise deeply fractious and partisan Israeli polity, and enjoying substantial prestige in public opinion as a bulwark of democracy — speaks with a unique authority in the country. ${ }^{168}$ Not surprisingly, then, its pronouncements in controversies involving the Occupied Territories are greeted with intense media coverage and public interest. ${ }^{169}$ In the view of one Israeli lawyer, "[M]uch of what the Court rules is accepted by at least the Jewish public as appropriate reading of law and morality; the majority looks to the Court and tends to internalize the values it vindicates." 170

Israeli political leaders, both within and outside of the military government, regularly invoke the authority of the High Court in rationalizing and defending policies in the Occupied Territories:

The military government thwarts critics by referring them to High Court decisions and by highlighting its willingness to subject its actions to judicial scrutiny. A similar approach is adopted by the Israeli government. .... [T] The legitimating effect has been at least partly successful in comforting and appeasing the Israeli public, and in attenuating voices of those who are inclined not to accept the moral ramifications of Israeli domination over the antagonistic Palestinian population. ${ }^{171}$

In fact, Palestinian legal victories in the High Court have been hailed within Israel as the surest evidence of the court's independence and the government's dedication to the rule of law. ${ }^{172}$ What might otherwise have stood as stern indictments of military government abuses were transformed into celebrations of the openness and affirmations of the democratic nature

the inquiry into the Hebron Mosque massacre. See Doug Struck, "Unprecedented Open Hebron Hearings Rivet Israelis," Baltimore Sun, 10 April 1994. Meanwhile this fact, and many like it, are so much a part of Palestinians' experience as to be utterly unremarkable.

168. Edelman, Courts (cited in note 58).

169. Shamir, 24 Law \& Soc'y Rev. at 795 (cited note 20).

170. Simon, 19 Yale J. Int'l L. at 6 (cited in note 52).

171. Id. at 8. According to another observer, present Israeli Prime Minister Rabin's standard reply to questions regarding human rights violations in the Occupied Territories is "It is all legal, everything is done according to the law." Negbi, 52 Jerusalem Q. 18, 19 (cited in note 123 ).

172. Some of the more florid praise for the court in the Hebrew press following its decision in the Elon Moreh case is reproduced in Shamir, 24 Law \& Soc'y Rev. at 795-96. Just one example he presents is Evron Boaz, writing in the Israeli daily Yediot Achronot: "The openmindedness of the court proves that Israel is a 'legitimate' state which is governed according to constitutional principles." See also Stendel, "The Arabs of Israel: Between Hammer and Anvil," 20 Israel Y.B. Hum. Rts. 287 (1991). 
of the Israeli state. ${ }^{173}$ Thus, even the relatively infrequent examples of successful lawyering on behalf of Palestinians in the Occupied Territories clearly had some legitimation costs. ${ }^{174}$

Not to be overlooked is the value of judicial approval to administrators themselves. If, as I have maintained elsewhere, ${ }^{175}$ legal institutions are most effective in legitimating the exercise of power by dominant groups for themselves, as opposed to those on whom the power is exerted, then this may be even more true of those specific, real individuals within the dominant group actually charged with the duty to apply the whip to the flesh, so to speak. Simon suggests that High Court approval for questionable military government policies, such as home demolitions, eased the moral qualms perhaps felt by area commanders-and, one might speculate further, by their deputies, down the chain of command to the actual soldiers who detonate the explosives or drive the bulldozers. ${ }^{176}$

It also seems likely that the military courts in the Occupied Territories, if only by their existence, painted for most Israelis a civilized visage over the uglier features of military rule. They provided a means of disciplining Palestinian resistance to military occupation that was compatible with Israelis' views of themselves and their government as democratic and constrained by law:

The military courts provided a legal veneer that enabled the Israelis to get their revenge on the Palestinians while still feeling clean and civilized. The Israeli security forces rarely did anything "illegal" in dealing with the Palestinians in the Occupied Territories. Every act of repression, no matter how arbitrary, was usually in line with some paragraph in the Israeli military code. When it wasn't, the code was changed to accommodate it. ${ }^{177}$

The same depersonalizing of repression that I suggested was a lubricant for maintaining functional relationships within the military courts may have been simultaneously a balm to the consciences of those who meted out this

173. This same process is observable in a number of the reports delivered by Israeli commissions of inquiry, in which judges have often played leading roles, including the recent one investigating the Hebron Mosque massacre. See Struck, Baltimore Sun (cited in note 167).

174. Just as certainly, at least some decisions of the High Court, or sequence of decisions, had delegitimating effects among diverse groups within Israel. E.g., the Court's reversal of the military acquisition of land for settlement in the Elon Moreh case provoked the ire of the Israeli right, and resulted in calls for Knesset legislation to curtail High Court jurisdiction in the Occupied Territories. See Hajjar, 2 Arab Stud. J. (cited in note 134). Simon, 19 Yale J. Int'l $L$. (cited in note 52), argues that the morally indefensible jurisprudence of the High Court in the matter of home demolitions and sealings has also delegitimated the Courtobviously within an entirely different segment of the Israeli population.

175. Bisharat, $43 \mathrm{Am}$. U.L. Rev. (cited in note 2).

176. Simon, 19 Yale J. Int'l L. Cf. Shehadeh, 23 J. Palestine Stud. (cited in note 98).

177. Friedman, Beirut 354 (cited in note 152). 
discipline-the military courts' judges and prosecutors. ${ }^{178}$ Writes Friedman: "'I'm sorry, it's nothing personal, my hands are tied,' the judge would tell the accused with his eyes. It's the law and l've got to live by the law. . . . Ten years in jail . . . Next case." "179

Needless to say, it is unlikely that we would have reached the recent historical juncture in Israeli-Palestinian relations had legitimation of the occupation of the West Bank and Gaza Strip among Israelis been complete. It was not, as groups such as B'Tselem, Yesh Gvul (the organization of conscientious objectors who refused to perform military duty in the Occupied Territories), and others are a testament. But these groups were either extraordinarily muted in their protests against Israeli policies or simply did not exist for the first 20 or so years of occupation. It was the acute crisis of the Intifada that brought them to the surface. ${ }^{180}$ Given the two worlds in which Palestinians and Israelis have lived, the overwhelming majority of Israelis have simply had no reason nor occasion to interrogate the reassuring image the military courts presented, or to explore the depth between image as they apprehended it and reality as Palestinians experienced it.

In some measure, then, it seems likely that the emergence of organized, effective public opposition to occupation within Israel was delayed, and its breadth probably restricted, by the aura of legality surrounding the military government. ${ }^{181}$ Lawyers for Palestinian interests, to the extent they helped to reproduce that aura, shared in intensifying its legitimating glow.

There is a need, still, to distinguish between legitimation effects truly assignable to the efforts of politically committed lawyers and those arising from other causes. Perhaps the only method to do this is to ask: In what respects might things have been different had these lawyers not come to the aid of Palestinian defendants and petitioners? Could they, by declining to practice in the military courts and the High Court, have denied the occupation administration the legitimacy it gained through the operation of these institutions? The answer, it seems evident enough, is no.

178. This is a slightly different point than I made in reference to the High Court's approval of military government policies. There, substantive measures received the blessings of the justices, arguably infusing occupation administrators with confidence in the moral rectitude, and international legality, of their acts. Military court judges, I am suggesting, were simply spared feelings of personal responsibility for enforcement of laws they may have acknowledged to be harsh, if not unjust. The value in both cases, however, stems from the need of groups exercising power to maintain internal cohesion and a sense of "mission" by providing normative justification for their acts-in other words, legitimating them-for themselves.

179. Friedman, Beirut 354.

180. B'Tselem, it will be recalled, was founded in 1988, several months after the outbreak of the uprising. The Association for Civil Rights in Israel, active within Israel itself, only expanded its mandate to include the Occupied Territories during the Intifada.

181. This is almost certainly true of the Israeli legal profession, which has been, with a few notable exceptions, and in contrast to its South African counterpart, almost entirely mute in the face of the military government's actions in the Occupied Territories. See Stanley Cohen, The Human Rights Movement in Istael and South Africa (1991). 
This is most obvious for the military courts. These courts did not depend for their foundation or continued functioning on the cooperation of politically committed members of the legal profession, and would have contributed to Israel's image abroad as a law-abiding nation even if lawyers sympathetic to Palestinian national interests had never taken up the invitation to practice in them. As we have seen, when Palestinian lawyers initially refused to practice in the military courts of the West Bank, Israeli lawyers-some progressive, and others not-simply filled the vacuum.

Neither was it a matter of choice for Palestinians to appear in these courts-they were, for the most part, simply hauled before military tribunals involuntarily as defendants. ${ }^{182}$ The issue facing Palestinian defendants was therefore not whether or not to be in court, but whether or not to seek representation. As most defendants opted for representation, the issue facing progressive Israeli and nationalist Palestinian lawyers was, thus, whether they, or some other lawyers less sympathetic to, and protective of, their clients' rights and interests, would undertake this representation.

Arguably the image conveyed of the military legal system was marginally more positive because Palestinian lawyers, and Israeli lawyers sympathetic to Palestinian interests, chose to practice in it. After all, one might have inferred that the lawyers saw the military legal system as capable of producing just results. ${ }^{183}$ But this is a relatively subtle point. Had these lawyers not elected to defend Palestinians in the military courts, most of the legitimacy coming from the military court system's appearance of formal legality would have accrued to the occupation administration anyway. On the other hand, Palestinian defendants would have enjoyed few, if any, of the benefits of representation by lawyers who understood and sympathized with them.

One might question the value of sympathy, as opposed to professional competence, in the provision of effective legal services to Palestinians. Perhaps Palestinian clients might have been better served by Israeli lawyers, fluent in Hebrew and trained in Israeli law, no matter what their political persuasion, than by sympathetic Palestinian lawyers, typically non-Hebrew speaking and less conversant in Israeli law and legal culture. Recall, however, the "social work" aspects, especially of practice in the military courts. In that connection, cultural affinity with clients and knowledge of Arabic were doubtless of greater utility than any technical legal skill. Shared political commitment or outlook, at least of a certain level, was probably also

182. This is untrue only of Palestinians appealing administrative sanctions before the military courts or objections committees. They, in theory, could choose to suffer these sanctions without mounting a defense.

183. This was evidently the judgment of at least some practicing lawyers. Recall the first sentences of the remarks by Felicia Langer I quoted in text at note 40 supra. 
essential to the establishment of the trust necessary to productive lawyerclient relations. ${ }^{184}$

It is also indisputable that, had lawyers sympathetic to Palestinian interests never ventured into the military courts, these institutions would have been permitted to function effectively unchallenged. Almost everything that is known about the myriad shortcomings of the military legal system is the product of the experience of lawyers working in the courts. Even moreso than in the exposure of torture and ill treatment of Palestinian detainees, these lawyers - in publications and speaking tours, in short-term strikes, in interviews and commentary in popular Arabic and Hebrew print and electronic media, in supplying information to journalists, consulates, nongovernmental organizations-have played a key role in exposing some of the less obvious ways in which the military legal system operates to the detriment of the Palestinian community. Thus, their practice has doubtless had some delegitimating effects on the system of military courts and government.

The situation with respect to practice in the High Court is not quite as clear-cut. Had no Palestinians from the Occupied Territories ever opted to file petitions before the High Court, there would have been no call to legitimize military government practices. However, it would have been much to expect of Palestinian claimants, facing the prospect of continued Israeli occupation of indeterminate length and suffering grievous abuse, to rest on their claims forever. As the military government's repressive power has never focused solely on political activists, it is no surprise that some Palestinians, especially the less politically involved, sought redress in the High Court.

Given the understandable choice of Palestinian deportees, administrative detainees, expropriated landowners, and others to fight military government actions against them, the question again was whether they would be represented by politically commitred lawyers or other lawyers with other motivations and interests. For the committed lawyers to nominate themselves for this role, under the circumstances, seems eminently reasonable. While supporters of military government policies could point to High Court oversight replete with unquestionably zealous advocacy for Palestinian interests, it seems likely that here, too, only a minor quantum of legitimation would have been added over that generated even in the absence of these lawyers.

Their advocacy has also insured that the High Court has been pushed to the limits of its ability and willingness to protect Palestinian rights. Only by putting the offer of High Court review fully to the test has the promise of

184. As a practical matter, the happy medium for many Palestinian clients has been the hiring of Israeli Arab lawyers, many of whom combine the desirable professional attributes of their Jewish Israeli counterparts with the cultural outlook and political sentiments of their clientele. Bisharat, Palestinian Lawyers 92-94 (cited in note 3). 
judicial oversight over the military government been exposed as, in many respects, a hollow one.

As I mentioned at the outset, local concerns over litigation in Israeli courts have always centered around legitimation costs to the virtual exclusion of all other considerations. I also suggested that this focus may grow out of some specificities associated with lawyering under harsh or repressive regimes, where the margin between benefits and costs of litigation is likely to be, as it is here, relatively thin. Nonetheless, it seems incumbent on us to enter some nonlegitimation costs into the equation.

Litigation both in the military courts and in the High Court consumes financial, human, and other resources. To some extent, at least, money spent on a legal defense is money not spent on education, new agricultural technology, or other essential goods. ${ }^{185}$ I can venture only a general estimate as to the total costs to the Palestinian community of litigation in Israeli courts. It seems likely, however, that for the period 1988-93, more than $\$ 3,000,000$ was spent in the Occupied Territories on legal fees for military court cases alone. ${ }^{186}$

These costs cannot be discounted or reasoned away. One has to assume, however, that the consistent willingness of Palestinians to invest in legal fees implies that the investment is seen as worthy, especially with precious interests at stake.

\section{CONCLUSIONS}

To restate my general thesis: lawyering under Israeli occupation has indeed involved both legitimation and other costs. While Israeli occupation per se never won legitimacy among Palestinians in the West Bank and Gaza Strip, lawyering in the courts of the occupier may have helped induce Palestinian compliance, channel anger and resentment against the military government into relatively harmless forms, and minimize friction among institutional actors. It also exacted the tangible costs of the litigation itself, including money and human resources. It is probable, too, that Israel's legal-

185. Do not assume, however, that the same funds would necessarily be available to support other forms of political activity. A wealthy landowner, e.g., might spend liberally to contest a land expropriation decree but would not contribute those same funds to a political party or movement. To the extent that such cases became a part of the struggle against occupation, litigation may have drawn social groups and resources into that struggle which would not otherwise have been part of it.

186. I multiplied an estimated average attorney's fee for military court cases by 40,000 , somewhat less than half of the 83,321 defendants IDF figures establish to have been tried in this period. I have never seen figures as to the percentage of Palestinian defendants who are unrepresented. My assumption of fewer than half is, I believe, somewhat conservative.

Although High Court litigation can be considerably more costly, the absolute number of High Court cases arising in the Occupied Territories is so much lower than the numbers of military court cases that their costs in aggregate are certainly far lower. 
istic style of governance in the Occupied Territories insulated it against sharper and more constant international criticism. And it seems indisputable that the military court system and the High Court legitimated military government among important segments of the Israeli public, not the least of which were government functionaries themselves, and retarded opposition to the occupation. We have seen, however, that the greatest proportion of the legitimating effects stemmed from Israeli policies which nationalist Palestinian and progressive Israeli lawyers had no power to resist, and the additional legitimation caused by the involvement of those lawyers was a but minor increment above that which would have accumulated in their absence.

The benefits of legal advocacy for Palestinian interests in Israeli courts, though certainly modest, are palpable. In the military courts they include relief to incarcerated defendants and their families and reduced sentences and fines through effective plea bargaining. Benefits achieved in the High Court include procedural rights, sometimes themselves providing a modicum of relief from severe sanctions, occasional deterrence of military government measures, and a few outright substantive victories-some of which, such as the limitations on the legal form of Israeli land acquisition in the Occupied Territories, are potentially momentuous. Direct informal interventions with administrators in the military government and longer-term appeals to the "court of public opinion"-both spheres of activity enabled by litigation-achieved occasional gains, perhaps most importantly in limiting the severity of physical maltreatment of thousands of Palestinians in Israeli custody. Lawyers also played a major role in exposing the flaws in the military court system and demonstrated the underlying paucity of the Israeli offer of access to the High Court.

I pointed at the outset to the complexity of the balancing task I was undertaking. Let me now be more explicit about the challenges I see to precise measurement of the kind of values to be balanced here. Identifying the costs and benefits is, in fact, the easiest step. Assigning them weight with any precision is nigh impossible.

On the benefit side, how does one determine the "weight" of a Palestinian defendant in military court spending three as opposed to six months in an Israeli prison? Or still more speculative, how does one measure the legitimation cost of an Israeli High Court decision validating a particular policy of the military government in the Occupied Territories? The difficulty continues even with some apparently tangible costs and benefits, at least if the goal is to assess them in relation to the advancement or retardation of a political movement. The fact that a detainee is released in half the time that would have otherwise been served, or pays a lesser fine, is tangible enough in its own terms-but how does one quantify the contribution of 
this to the struggle to end Israeli occupation and establish Palestinian selfdetermination?

This question returns us to the classic tension between concrete, immediate, interests of individual clients and abstract, long-term, communal objectives of social and political movements that defines "cause lawyering." 187 This is truly only a tension, rather than an opposition-after all, a movement whose individual constituents are ground to dust enjoys scant odds for success. But in this connection one cannot lean on individual clients' choice to seek the services of lawyers as an index of their value, as that choice may reflect the calculations of narrow self-interest only.

I suggested previously the possibility that lawyers, seeing their clients' cases as individual ones, may have unwittingly assisted in directing Palestinian defendants in the military courts into a relatively nonconfrontational approach. I proposed as well that a more confrontational approach, while exacting a greater toll on individual defendants, might have better served the general Palestinian community under occupation in the long term. It could have raised the costs of the military government, in turn, perhaps, evoking stronger Israeli public criticism and opposition to occupation at an earlier point.

But this cannot be known. If the failure to adopt a tactic of noncooperation was indeed a failure, two points should be made. First, the failure was one of tactics and does not implicate lawyers' strategic decision to enter the courts of the occupier. Indeed, for reasons that may be obvious, the success of the particular tactic of noncooperation I mentioned (refusing to plea bargain and contesting each case at every level) would have depended even more on effective lawyering than the tactic actually adopted. Second, although lawyers might share some responsibility for not using that tactic, most of the blame must be laid at the feet of the political leadership of the nationalist movement under occupation, which never provided guidance in this matter.

In defending the decision of lawyers and clients in the Occupied Territories to enter Israeli courts and wrest from them whatever minimal protections were possible, I prefer to imagine that I have done more than to opt for the concrete over the abstract, simply because the former is relatively palpable, or susceptible to measurement, and the other not. Another view of these poles is that they embody elements of certainty and uncertainty, again, though only relatively so. There is, I think, logical appeal in the

187. A 1992 memorandum to members of an international project for the study of "cause lawyering" by Austin Sarat and Stuart Scheingold states: "As we see it, cause lawyering entails a self-conscious choice to give priority to causes rather than to client service, as such. Of course, serving causes and serving clients are not necessarily mutually exclusive although there are well-recognized tensions between them-with both ethical and organizational implications. Indeed, it is largely these tensions that provide the problematic on which the project on cause lawyering rests." 
aphorism "a bird in the hand is worth two in the bush." But beyond that even, my effort has been to account for and incorporate the intangible and distant legitimation costs into the balance, not simply to scoff at them and cast them aside as speculative. As I warned, however, the accuracy of my assessment is best left to the reader's discretion.

The political and institutional context within which lawyers for Palestinian interests have operated-military rule by a foreign occupier-is, in many of its features, unique, and thus cannot be compared with other locales in which lawyering for political and social causes has occurred. On the other hand, there are some lessons of more general application to be drawn from this study. As mentioned at the outset, most of those who have fretted over the legitimating effects of legal practice have done so where litigation has actually been pursued and resources devoted to it.

The West Bank lawyers' strike offers an unusual opportunity to evaluate an attempt to follow the other path-to refrain from legal practice. What did the strike accomplish? Does it provide a useful model for lawyers confronting injustice, whether inflicted by highly repressive or liberal democratic states? Quite to the contrary, I think, the strike demonstrates the likely piffalls of withdrawal from the courts, at least as a long-term strategy.

The strike cannot be fairly designated a "failure" without first evaluating it in its own terms, and according to its own goals, whether stated or implicit. The strike was never calculated to embarass or pressure the Israeli authorities, into any particular concessions; the lawyers issued no demands or set an expiration date for the boycott. Nor was the strike really designed to frustrate or impede the functioning of the military courts. ${ }^{188}$

It was, instead, a purely symbolic act-an absolute shunning of Israeli authority, designed to communicate the lawyers' steadfast hostility toward the occupation to primarily Arab audiences. As such, the strike scored a success, at least in its early months, perhaps even for years. The spectacle of elite members of the Palestinian community almost fully renouncing lucrative, established careers to express opposition to Israeli rule was, no doubt, an inspiring one for many Palestinians, especially in the context of the local cultural logic of honor, commitment to which was best demonstrated by the sacrifice of material interest.

Not sufficiently inspiring, however, that other occupational groups and sectors within the Palestinian community were moved to follow the lawyers' example, as the latter had expected and hoped. The strike was indeed a conscious attempt to assert leadership within the emerging nationalist movement in the Occupied Territories; for many reasons, one surmises, and for better or for worse, the lawyers' play for a vanguard role never came to

188. Striking lawyers I interviewed, e.g., had no criticisms of the Jewish or Arab lawyers from Israel who worked in the military courts, thereby helping to keep these institutions running. 
fruition. ${ }^{189}$ Whatever others made of the strike at the outset, it was, if the reports of those who resumed practice are to be believed, at their clients' urging that they abandoned the strike.

Events unfolded in such a way as to dissipate the force of even the strike's most basic communicative content. The first major break was the defection from the strike of about a dozen prominent lawyers from the Ramallah area in 1971 and their resumption of practice that eventuallly encompassed the military courts. This contingent grew, both through further defections and the addition of new law graduates, including a disproportionate share of the more highly motivated and capable among them.

Meanwhile, other recent graduates joined the strike, impelled, in many cases, as much by the local market for legal services and the promise of a stipend from the Jordanian Lawyers' Union as by belief in the strike's original rationale. ${ }^{190}$ The composition of the striking contigent was slowly transformed and its collective identity distorted by the presence of a majority distinguished by the fact that they had never set foot in a courtroom-in local views, the distinctive province of the profession. ${ }^{191}$ Nor was there a stage in not working for the public display of technical legal knowledge that constitutes the profession's claims to special authority. ${ }^{192}$ The striking contingent became increasingly isolated, and its contributions, as a group, to the community dwindled.

Some strikers became journalists, teachers, shopkeepers, and the like, both out of financial interest and for personal fulfillment, but with the effect of blurring the border between the legal profession and other occupations. As it required something less than genius to sign one's name to the union roster and collect a stipend, the wider community was left to wonder as to the motivations, competence, mission, even the very professional identity of the striking contingent. ${ }^{193}$

189. I cannot reconstruct all the reasons other groups failed to engage in strikes. The most likely is that lawyers had resources, including money and support from a fairly powerful institution outside the Occupied Territories-the Jordanian Lawyers' Union-that other occupational groups lacked.

190. See supra note 32. By no means was the breakdown of working and striking new graduates simply between the capable and the less capable, however. Financial need, family connections with established members of the profession, and a number of other factors were significant in determining individuals' choices.

191. This was not true of all the striking lawyers, a small minority of whom continued to practice in the Islamic and Christian religious courts in the region. These courts, for a variety of reasons, offered but a peripheral arena for the performance of lawyerly work.

192. The striking faction tried to address this problem by staging public defenses of a "thesis" - a new requirement for passage from apprenticeship to "master" lawyer status among the strikers, adopted because "masters" who were not practicing offered little in the way of training to their apprentices. The one I attended in the strikers' headquarters in Beit Hanina had a distinctly wistful air.

193. There was a point at which payment of the stipend, though still funneled through the Jordanian Lawyers' Union, was assumed by the Jordanian-Palestinian Joint Committee distributing the "Steadfastness Funds." The amwaal as-sumud were established by the Arab states in 1978 to support the Palestinian communities under occupation. Still later, the 
This would be only an intriguing tale were it all the outgrowth of circumstances unique to the West Bank. Certain of its twists no doubt are; others, I believe, are not. For example, the degree to which the striking contingent's standing suffered is to a considerable extent a result of the contemporary West Bank legal profession's insubstantial roots in Palestinian society, dating only to the British Mandate era. ${ }^{194} \mathrm{~A}$ society in which the profession was indigenous and well-rooted, in contrast, might receive a long-term strike with considerably greater understanding and tolerance. Similarly, a strike might not have the same blurring effect on the boundaries of a legal profession not defined so thoroughly through its work in courts.

Yet the social position of legal professions in many non-Western, postcolonial societies may exhibit greater parallels to the Palestinian profession than to their progenitors of the metropole. And it is hard to imagine any legal profession that would not suffer a loss of authority, and thus efficacy, due to the sustained nonuse of the very skills and technical knowledge that define its purported social value. ${ }^{195}$

The strike might have been effective had it genuinely halted or even slowed the functioning of the military courts, even though this was not a consciously articulated goal. That, as we know, did not occur. The reader may protest, since other lawyers stepped in to fill the gap in services left by the striking Palestinian attorneys, that ours is not a pristine test of what may happen when lawyers or a political cause choose not to pursue legal struggle. This, however, may itself be the strike's best lesson.

Certainly the specific expedient by which the strike was bypassed-a military order authorizing Israeli lawyers to appear in West Bank courtswas unique to the particular context. In a sense, it was the fact that West Bank lawyers did not have an enforceable monopoly over the supply of legal services in the area that would have foiled any attempt to jam the workings of the military courts.

Yet how often would such a monopoly arise, particularly one controlled by lawyers committed to a political cause? On reflection, the ability of the West Bank legal profession to sustain unanimity in honoring the strike for four years-essentially mandating that an entire group renounce its profession一was a remarkable feat, involving great personal sacrifice, at least of the strike's original proponents. To a considerable extent, this unanimity

number of stipends given to the strikets was fixed, after which point new law graduates queued for their receipt. Bisharat, Palestinian Lawyers 156 (cited in note 3).

194. I review the history of the local profession and the implications of its status as a profession imposed through colonialism in id. at 18-30.

195. This critique is limited to long-term strikes or other kinds of withdrawal from practice by the legal profession. While the numerous short-term strikes called by working lawyers in the Occupied Territories-ranging from one day to, in one instance during the Intifada, two months-have also not, to my knowledge, achieved meaningful reforms in the military court system; they have also had nothing of the ruinous impact of the long-term boycott. 
was a function of the fact that the strike was a part of a national struggle, about which there was virtually complete political consensus in Palestinian society.

Lawyers working for political causes over which there is less consensus-many intrasocietal ones, for example-are far less likely to be able even to approach the level of professional discipline achieved in the West Bank lawyers' strike. In such cases, politically committed lawyers will very likely be faced with just the question faced by lawyers fighting Israeli occupation: Should they, or other lawyers, represent the victims of the authority they oppose? This question may not be confronted if the only victims involved are hard core political cadres willing to suffer privations indefinitely to make a political statement. Or the question may be delayed if the victims are not just movement activists, but are likely facing a period of temporary repression.

Where, however, the scope of repression is broad, and its duration more than temporary, common citizens will seek relief-and legal relief, where the courts of the land offer even a glimmer of hope. This was precisely the situation in the Occupied Territories: many Palestinian victims of military government power were not just the veteran activists of the national movement but were landowners, laborers, and others who had no particularl involvement in political life. The answer to whether activist lawyers or others should take up the fight on behalf of the victims of repression in circumstances like these seems relatively easy.

Those who have questioned the value of litigation in movements for social or political change have tallied its costs to those movements, sometimes overlooking the toll, both tangible and intangible; that litigation can take on the state (and perhaps, on hostile forces in civil society). I have tried to demonstrate that lawyers working to defend Palestinian interests in Israeli courts have indeed occasionally inflicted such costs in confrontations with the harshly repressive military government in the Occupied Territories. This was evident, for example, in the plea bargaining leverage garnered through the conduct of "mini-trials" challenging admissibility of confessions in the military courts. It was also apparent in the military government's occasional abandonment of measures once the prospect of High Court litigation was raised. Thus, the special skills lawyers could employ to "run up the meter" on the state translated directly into meaningful gains for their clients, at least in some circumstances.

I repeat: A fundamental condition for this success is the fact that military government in the West Bank and Gaza Strip, while repressive, is an extension of a state in which democratic principles and the notion of the rule of law are taken seriously, whether or not they are always realized. Lawyers' ability to impose costs on the military government was a function of Israel's willingness to saddle the occupation administration with obligations 
to conform to certain procedures and to provide courts to challenge any violations of the same.

Needless to say, many repressive states will not offer such opportunities, and thus will not provide lawyers the kind of leeway available in the Occupied Territories. Belligerent occupation by liberal democratic states, moreover, may not be a common phenomenon. But a different mix of vectors emanating from civil society and international pressure-where, for example, a state may face fewer internal constraints but because of greater dependence on foreign support, is accountable to vigilant outsiders-may lead to creation of a similar space for positive contributions through litigation in other kinds of repressive environments. The example of lawyering under Israeli occupation does not prove the existence of this space in all cases but hints at the rewards attainable for those who search it out and fight to broaden it.

Ellmann astutely notes that among the benefits to be weighed in gauging the worth of lawyering in a climate of oppression are those which only accrue following a transformation to a more just society-for South Africa, the preservation of principles valorizing the independence of the judiciary and respect for the rule of law. ${ }^{196}$ At first blush, this claim is troublingafter all, it offers justification for a decision based on considerations visible only through hindsight. Is it proper for lawyers and others, pondering whether to enter the courts of a repressive state prospectively, to weight the scale with considerations that pertain to an uncertain future and so can be, at the most, speculative?

More data are certainly needed before firm conclusions can be drawn. But the juxtaposition of Ellmann's example with mine suggests that confidence in some future benefits from lawyering against repression may not always be ill-founded, even while the specific benefits themselves and the date of their eventual realization remain hazy.

Though the particular principles identified by Ellmann for South Africa are unlikely to be part of the specific legacy of Israeli occupationIsraeli courts simply did not demonstrate the independence from executive power that the South African judiciary did-other resources have been developed that will be of substantial value to the independent Palestinian society now struggling to be born. One might cite the model of judicial professionalism arguably passed on by military court judges to West Bank and Gaza lawyers-themselves likely candidates for membership in a future Palestinian judiciary.

Most eminent, however, is the cadre of lawyers and institutions dedicated to the protection of human rights that has emerged in the Occupied Territories. It is not a coincidence that the human rights movement in the West Bank and Gaza Strip is far more developed than it is in surrounding,

196. Ellman, Time of Trouble (cited in note 38) and this Symposium. 
largely autocratic, Arab societies. ${ }^{197}$ On the contrary, this movement flourished in the particular mix of legalism and repression that characterized Israeli military rule. Against the strong-and in Palestinians' eyes, deliberately created-pressures to leave the Occupied Territories, the opportunities in legal practice and for work in the human rights field helped to keep talented and educated members of the community "gainfully employed," so to speak, in their land. Even had nothing else come of their efforts, the individuals protected and nurtured through the period of Israeli rule bring to the new Palestinian government valuable assets.

There were tantalizing signs that the human rights movement in the Occupied Territories had not even reached its full potential in the pre-Oslo accords period but was yearly gaining sophistication and expanding the horizons of the legal struggle for Palestinian rights. Signs of this growth were evident, for example, in a successful wrongful death suit against Israeli undercover agents operating in the Occupied Territories litigated in an Israeli civil court in 1992, the first of its kind. ${ }^{198}$ Likewise, a civil suit filed in U.S. federal court against American manufacturers of tear gas whose products had caused deaths among Palestinians in the West Bank and Gaza Strip was to be heard in 1993.199

There is evidence that lawyers and human rights organizations are already readjusting priorities in the new transitional period. Palestinian organizations al-Haq and the Gaza Centre for Rights and Law, mainstays of the local human rights community in the pre-Oslo accords era, are speaking out strongly against rights violations by the new Palestinian Authority ${ }^{200}$ and expanding their agendas to address important social issues long subordinated to the "national question," such as the legal rights of Palestinian women. ${ }^{201}$

A mature human rights movement led in part by experienced, sophisticated legal practitioners ${ }^{202}$ and tested in the fire of Israeli occupation will

197. See Jill Crystal, "The Human Rights Movement in the Arab World," 16 Hum. Rts. Q. 435 (1994).

198. John Immanuel, "Palestinian Shot by IDF Undercover Unit Awarded NIS 165,000," Jerusalem Post, 6 Nov. 1992.

199. The suit was initiated by lawyers with the Center for Constitutional Rights in New York. Holly Knaus \& Julie Gozan, "Taking Tear Gas to Trial," Multinat'l Monitor, Jan./Feb. 1993. Palestinian lawyers in the Occupied Territories have assisted in locating potential plaintiffs and documenting claims.

200. Peter Ford, "Palestinian Police Probed after Death of Beaten Detainee," Christian Sci. Monitor, 11 July 1994, at 3; Agence France Presse, "Rights Group Protests Ban on Gaza Meetings," 29 Sept. 1994, and "Rights Group Protests New Political Restrictions in Gaza," 6 Oct. 1994.

201. al-Haq, known in English until the mid-1980s as "Law in the Service of Man" (a direct translation of the Arabic al-Qanun min ajl al-Insaan; insaan or "person" in Arabic, has no gender reference), sponsored a four-day conference in Toronto in mid-1994 on "Women, Justice, and Law: Towards the Empowerment of Palestinian Women." "Palestinian Women Begin to Fight for Rights," Toronto Star, 29 Oct. 1994.

202. Eg., Raja Shehadeh, perhaps the best-known Palestinian advocate for human rights outside the region, has become affiliated with the independent human rights commis- 
stand Palestinian society in good stead in the coming years. In the midst of the disquieting signals already manifest in the areas ruled by the Palestinian Authority, these dedicated men and women shield the spark of a Palestinian democracy against the gusts of new forms of repression.

sion established at the initiative of Dr. Hanan Ashrawi (the Palestinian spokesperson for the Madrid peace talks). 
HeinOnline -- 20 Law \& Soc. Inquiry 4061995 